This PDF is a selection from a published volume from the National Bureau of Economic Research

Volume Title: Price Index Concepts and Measurement

Volume Author/Editor: W. Erwin Diewert, John S. Greenlees and Charles R. Hulten, editors

Volume Publisher: University of Chicago Press

Volume ISBN: 0-226-14855-6

Volume URL: http://www.nber.org/books/diew08-1

Conference Date: June 28-29, 2004

Publication Date: December 2009

Chapter Title: Durables and Owner-Occupied Housing in a Consumer Price Index

Chapter Author: W. Erwin Diewert

Chapter URL: http://www.nber.org/chapters/c5089

Chapter pages in book: (445 - 500) 


\title{
Durables and Owner-Occupied Housing in a Consumer Price Index
}

\author{
W. Erwin Diewert
}

\subsection{Introduction}

When a durable good (other than housing) is purchased by a consumer, national consumer price indexes typically attribute all of that expenditure to the period of purchase, even though the use of the good extends beyond the period of purchase. ${ }^{1}$ This is known as the acquisitions approach to the treatment of consumer durables in the context of determining a pricing concept for the Consumer Price Index (CPI). However, if one takes the cost-of-living approach as the measurement objective for the CPI, then it is more appropriate to take the cost of using the services of the durable good during the period under consideration as the pricing concept. There are two broad approaches to estimating this imputed cost for using the services of a durable good during a period:

W. Erwin Diewert is a professor of economics at the University of British Columbia and a research associate of the National Bureau of Economic Research.

This research was supported by Statistics Sweden and a Social Sciences and Humanities Research Council of Canada grant. The author thanks Bert Balk, Kevin Fox, John Greenlees, Rosmundur Gudnason, Alan Heston, Peter Hill, Johannes Hoffman, Charles Hulten, Arnold Katz, Anders Klevmarken, Timo Koskimäki, Anne Laferrère, Alice Nakamura, Marshall Reinsdorf, and Carmit Schwartz for helpful comments on earlier versions of this chapter. The above people and institutions are not responsible for any errors or opinions expressed in this chapter. Some of the material in this chapter overlaps with chapter 23 in the Consumer Price Index Manual: Theory and Practice (International Labor Organization et al. 2004).

1. This treatment of the purchases of durable goods dates back at least to Alfred Marshall (1898, 594-95): "We have noticed also that though the benefits which a man derives from living in his own house are commonly reckoned as part of his real income, and estimated at the net rental value of his house; the same plan is not followed with regard to the benefits which he derives from the use of his furniture and clothes. It is best here to follow the common practice, and not count as part of the national income or dividend anything that is not commonly counted as part of the income of the individual." 
- If rental or leasing markets for a comparable consumer durable exist, then this market rental price could be used as an estimate for the cost of using the durable during the period. This method is known as the rental equivalence approach.

- If used or second-hand markets for the durable exist, then the imputed cost of purchasing a durable good at the beginning of the period and selling it at the end could be computed, and this net cost could be used as an estimate for the cost of using the durable during the period. This method is known as the user cost approach.

The major advantages of the acquisitions approach to the treatment of consumer durables are as follows:

- It is conceptually simple and entirely similar to the treatment of nondurables and services.

- No complex imputations are required.

The major disadvantage of the acquisitions approach, compared to the other two approaches, is that the acquisitions approach is not likely to reflect accurately the consumption services of consumer durables in any period. Thus, suppose that real interest rates in a country become very high due to some sort of macroeconomic crisis. Under these conditions, typically purchases of automobiles, houses, and other long-lived consumer durables drop dramatically, perhaps to zero. However, the actual consumption of automobile and housing services of the country's population will not fall to zero under these circumstances: consumers will still be consuming the services of their existing stocks of automobiles and houses. Thus, for at least some purposes, rather than taking the cost of purchasing a consumer durable as the pricing concept, it will be more useful to take the cost of using the services of the durable good during the period under consideration as the pricing concept.

The previous paragraphs provide a brief overview of the three major approaches to the treatment of consumer durables. In the remainder of this introduction, we explore these approaches in a bit more detail and give the reader an outline of the detailed discussion that will follow in subsequent sections.

We first consider a formal definition of a consumer durable. By definition, a durable good delivers services longer than the period under consideration. ${ }^{2}$ The System of National Accounts, 1993 (SNA) defines a durable good as follows:

In the case of goods, the distinction between acquisition and use is analytically important. It underlies the distinction between durable and nondurable goods extensively used in economic analysis. In fact, the distinc-

2. An alternative definition of a durable good is that the good delivers services to its purchaser for a period exceeding three years: "The Bureau of Economic Analysis defines consumer durables as those durables that have an average life of at least 3 years" (Katz 1983, 422). 
tion between durable and non-durable goods is not based on physical durability as such. Instead, the distinction is based on whether the goods can be used once only for purposes of production or consumption or whether they can be used repeatedly, or continuously. For example, coal is a highly durable good in a physical sense, but it can be burnt only once. A durable good is therefore defined as one which may be used repeatedly or continuously over a period of more than a year, assuming a normal or average rate of physical usage. A consumer durable is a good that may be used for purposes of consumption repeatedly or continuously over a period of a year or more. (Eurostat et al. 1993, 208)

According to the SNA definition, durability is more than the fact that a good can physically persist for more than a year (this is true of most goods): a durable good is distinguished from a nondurable good due to its ability to deliver useful services to a consumer through repeated use over an extended period of time.

Because the benefits of using the consumer durable extend over more than one period, it does not seem appropriate to charge the entire purchase cost of the durable to the initial period of purchase. If this point of view is taken, then the initial purchase cost must be distributed somehow over the useful life of the asset. This is a fundamental problem of accounting. ${ }^{3}$ Hulten (1990) explains the consequences for accountants of the durability of a purchase as follows:

Durability means that a capital good is productive for two or more time periods, and this, in turn, implies that a distinction must be made between the value of using or renting capital in any year and the value of owning the capital asset. This distinction would not necessarily lead to a measurement problem if the capital services used in any given year were paid for in that year; that is, if all capital were rented. In this case, transactions in the rental market would fix the price and quantity of capital in each time period, much as data on the price and quantity of labor services are derived from labor market transactions. But, unfortunately, much capital is utilized by its owner and the transfer of capital services between owner and user results in an implicit rent typically not observed by the statistician. Market data are thus inadequate for the task of directly estimating the price and quantity of capital services, and this has led to the development of indirect procedures for inferring the quantity of capital, like the perpetual inventory method, or to the acceptance of flawed measures, like book value. (120-1)

3. "The third convention is that of the annual accounting period. It is this convention which is responsible for most of the difficult accounting problems. Without this convention, accounting would be a simple matter of recording completed and fully realized transactions: an act of primitive simplicity" (Gilman 1939, 26). "All the problems of income measurement are the result of our desire to attribute income to arbitrarily determined short periods of time. Everything comes right in the end; but by then it is too late to matter" (Solomons 1961, 378). Note that these authors do not mention the additional complications that are due to the fact that future revenues and costs must be discounted to yield values that are equivalent to present dollars. 
Thus, the treatment of durable goods is more complicated than the treatment of nondurable goods and services due to the simple fact that the period of time that a durable is used by the consumer extends beyond the period of purchase. For nondurables and services, the price statistician's measurement problems are conceptually simple: prices for the same commodity need only be collected in each period and compared. However, for a durable good, the periods of payment and use do not coincide, so complex imputation problems arise if the goal of the price statistician is to measure and compare the price of using the services of the durable in two time periods.

The three major approaches to the treatment of durables will be discussed more fully in sections $12.2,12.3$, and 12.4 . However, there is a fourth approach to the treatment of consumer durables that has only been used in the context of pricing owner-occupied housing $(\mathrm{OOH})$, and that is the payments approach. ${ }^{4}$ This is a kind of a cash flow approach, which is not entirely satisfactory, ${ }^{5}$ so it will not be discussed any further.

The preceding three approaches to the treatment of durable purchases can be applied to the purchase of any durable commodity. However, historically, it turns out that the rental equivalence and user cost approaches have only been applied to owner-occupied housing. ${ }^{6}$ In other words, the acquisitions approach to the purchase of consumer durables has been universally used by statistical agencies, with the exception of owner-occupied housing. A possible reason for this is tradition; that is, Marshall set the standard, and statisticians have followed his example for the past century. However, another possible reason is that unless the durable good has a very long useful life, it usually will not make a great deal of difference in the long run, regardless of whether the acquisitions approach or one of the two alternative approaches is used. ${ }^{7}$

A major component of the user cost approach to valuing the services of owner-occupied housing is the depreciation component. General methods

4. This is the term used by Goodhart (2001, F350-F351).

5. This approach recognizes some costs of housing (such as nominal mortgage interest) but ignores other costs (such as the opportunity cost of equity funds tied up in the housing unit). It also ignores some benefits, such as anticipated appreciation of the equity part of the housing unit, and this factor is particularly important when there is high or moderate inflation. Thus, when there is very high inflation over the period and mortgage interest payments blow up, the payments approach will indicate a big increase in price of housing. However, the real cost to the homeowner will not be proportional to these monetary interest payments; there is an offsetting gain due to appreciation of the underlying housing asset. Put another way, an interest rate is a rather complex type of price. It is a payment for the use of funds over a specified time period. But the value of money is not the same at the beginning and end of the specified time period, and this fact should be taken into account if interest enters a CPI. This type of reasoning suggests that nominal interest rates should not be used in a CPI, but some form of real interest rate could be acceptable, as in the user cost approach (to be discussed later).

6. The Boskin Commission recommended that a flow of services approach be applied to all types of consumer durables, but this recommendation has not yet been implemented; see Boskin et al. (1996).

7. See Diewert (2002, 617-9). 
for determining depreciation rates when information on used-asset prices is available ${ }^{8}$ have been worked out by Hall (1971), Beidelman (1973, 1976), and Hulten and Wykoff (1981a, 1981b, 1996). ${ }^{9}$ However, many durables (such as housing) are custom produced, and it turns out that the standard methods for determining depreciation rates are more difficult to implement. The special problems caused by these uniquely produced consumer durables are considered in section 12.5 .

Sections 12.6 through 12.11 treat some of the special problems involved in implementing the user cost and rental equivalence methods for valuing the services provided by owner-occupied housing. Section 12.6 presents a derivation for the user cost of $\mathrm{OOH}$ and various approximations to it. Section 12.7 looks at some of the problems associated with obtaining constantquality prices for housing. Section 12.8 considers some of the costs that are tied to home ownership, while section 12.9 considers how a landlord's costs might differ from a homeowner's costs. This material is relevant if the rental equivalence approach to valuing the services of $\mathrm{OOH}$ is used: care must be taken to remove some costs that are imbedded in market rents that homeowners do not face.

Section 12.10 tries to bring together all of the material on the problems associated with pricing owner-occupied housing and to outline possible CPI measurement strategies. Finally, section 12.11 concludes with another approach to the measurement of the services provided by $\mathrm{OOH}$ : the opportunity cost approach, which sets the price of $\mathrm{OOH}$ to the maximum of its user cost and its market rent. The very interesting critique of the user cost approach made by Verbrugge (2006) is also discussed in this final section.

\subsection{The Acquisitions Approach}

The net acquisitions approach to the treatment of owner-occupied housing is described by Goodhart as follows:

The first is the net acquisition approach, which is the change in the price of newly purchased owner occupied dwellings, weighted by the net purchases of the reference population. This is an asset based measure, and therefore comes close to my preferred measure of inflation as a change in the value of money, though the change in the price of the stock of existing houses rather than just of net purchases would in some respects be even better. It is, moreover, consistent with the treatment of other durables. A few countries, e.g., Australia and New Zealand, have used it, and it is, I understand, the main contender for use in the Euro-area Harmonized

8. General models relating capital services, depreciation, and asset values in a set of vintage accounts have been worked out by Jorgenson $(1973,1989)$ and Hulten $(1990,127-9 ; 1996$, 152-60).

9. See also Jorgenson (1996) for a review of the empirical literature on the estimation of depreciation rates. 
Index of Consumer Prices (HICP), which currently excludes any measure of the purchase price of (new) housing, though it does include minor repairs and maintenance by home owners, as well as all expenditures by tenants. (2001, F350)

Thus, the weights for the net acquisitions approach are the net purchases of the household sector of houses from other institutional sectors in the base period. Note that in principle, purchases of second-hand dwellings from other sectors are relevant here; for example, a local government may sell rental dwellings to owner occupiers. However, typically, newly built houses form a major part of these types of transactions. Thus, the long-term price relative for this category of expenditure will be primarily the price of (new) houses (quality adjusted) in the current period relative to the price of new houses in the base period..$^{10}$ If this approach is applied to other consumer durables, it is extremely easy to implement: the purchase of a durable is treated in the same way as a nondurable or service purchase is treated.

One additional implication of the net acquisitions approach is that major renovations and additions to owner-occupied dwelling units could also be considered in scope for this approach. In practice, these costs typically are not covered in a standard consumer price index. The treatment of renovations and additions will be considered in more detail in section 12.8.4.

Traditionally, the net acquisitions approach also includes transfer costs relating to the buying and selling of second-hand houses as expenditures that are in scope for an acquisitions-type consumer price index. These costs are mainly the costs of using a real estate agent's services and asset-transfer taxes. These transfer costs will be further discussed in sections 12.8.2 and 12.8.5.

The major advantage of the acquisitions approach is that it treats durable and nondurable purchases in a completely symmetric manner, and thus no special procedures have to be developed by a statistical agency to deal with durable goods. The major disadvantage of this approach is that the expenditures associated with this approach will tend to understate the corresponding expenditures on durables that are implied by the rental equivalence and user cost approaches. ${ }^{11}$

Some differences between the acquisitions approach and the other approaches are as follows:

- If rental or leasing markets for the durable exist and the durable has a long useful life, then the expenditure weights implied by the rental

10. This price index may or may not include the price of the land that the new dwelling unit sits on; for example, a new house price construction index would typically not include the land cost. The acquisitions approach concentrates on the purchases by households of goods and services that are provided by suppliers from outside the household sector. Thus, if the land on which a new house sits was previously owned by the household sector, then presumably, the cost of this land would be excluded from an acquisitions-type new house price index.

11. See Diewert $(2002,618-9)$ on this point. 
equivalence or user cost approaches will typically be much larger than the corresponding expenditure weights implied by the acquisitions approach.

- If the base year corresponds to a boom year (or a slump year) for the durable, then the base-period expenditure weights may be too large or too small. Put another way, the aggregate expenditures that correspond to the acquisitions approach are likely to be more volatile than the expenditures for the aggregate that are implied by the rental equivalence or user cost approaches.

- In making comparisons of consumption across countries where the proportion of owning versus renting or leasing the durable varies greatly, ${ }^{12}$ the use of the acquisitions approach may lead to misleading crosscountry comparisons. The reason for this is that opportunity costs of capital are excluded in the net acquisitions approach, whereas they are explicitly or implicitly included in the other two approaches.

More fundamentally, whether the acquisitions approach is the right one depends on the overall purpose of the index number. If the purpose is to measure the price of current-period consumption services, then the acquisitions approach can only be regarded as an approximation to a more appropriate approach (which would be either the rental equivalence or user cost approach). If the purpose of the index is to measure monetary (or nonimputed) expenditures by households during the period, then the acquisitions approach is preferable, because the rental equivalence and user cost approaches necessarily involve imputations.

\subsection{The Rental Equivalence Approach}

The rental equivalence approach simply values the services yielded by the use of a consumer durable good for a period by the corresponding market rental value for the same durable for the same period of time (if such a rental value exists). This is the approach taken in the System of National Accounts, 1993 for owner-occupied housing:

As well-organized markets for rented housing exist in most countries, the output of own-account housing services can be valued using the prices of the same kinds of services sold on the market with the general valuation rules adopted for goods and services produced on own account. In other words, the output of housing services produced by owner-occupiers is valued at the estimated rental that a tenant would pay for the same accommodation, taking into account factors such as location, neighbour-

12. According to Hoffmann and Kurz (2002, 3-4), about 60 percent of German households lived in rented dwellings, whereas only about 11 percent of Spaniards rented their dwellings in 1999. 
hood amenities, etc. as well as the size and quality of the dwelling itself. (Eurostat et al. 1993, 134)

However, the SNA follows Marshall $(1898,595)$ and does not extend the rental equivalence approach to consumer durables other than housing. This seemingly inconsistent treatment of durables is explained in the SNA as follows:

The production of housing services for their own final consumption by owner-occupiers has always been included within the production boundary in national accounts, although it constitutes an exception to the general exclusion of own-account service production. The ratio of owner-occupied to rented dwellings can vary significantly between countries and even over short periods of time within a single country, so that both international and intertemporal comparisons of the production and consumption of housing services could be distorted if no imputation were made for the value of own-account services. (Eurostat et al. 1993, 126)

Eurostat's (2001) Handbook on Price and Volume Measures in National Accounts also recommends the rental equivalence approach for the treatment of the dwelling services for owner-occupied housing:

The output of dwelling services of owner occupiers at current prices is in many countries estimated by linking the actual rents paid by those renting similar properties in the rented sector to those of owner occupiers. This allows the imputation of a notional rent for the service owner occupiers receive from their property. (99)

The U.S. statistical agencies, the Bureau of Labor Statistics (BLS) and the Bureau of Economic Analysis (BEA), both use variants of the rental equivalence approach to value the services of owner-occupied housing. Katz describes the BEA procedures as follows:

Basically, BEA measures the gross rent (space rent) of owner occupied housing from data on the rent paid for similar housing with the same market value. To get the service value that is added to GNP (gross housing product), the value of intermediate goods and services included in this figure (e.g., expenditures for repair and maintenance, insurance, condominium fees, and closing costs) are subtracted from the space rent. To obtain a net return (net rental income), depreciation, taxes, and net interest are subtracted from, and subsidies added to, the service value. (Katz 1983, 411)

Basically, the BEA applies estimated rent to asset-value ratios for rental units to asset values for owner-occupied dwellings of the same type in order to obtain estimated rents for these owner-occupied units.

Another method for determining rental price equivalents for owned consumer durables is to ask owners what they think their durables would rent for. This approach was used by the BLS in order to determine expenditure 
weights for owner-occupied housing prior to the $1998 \mathrm{CPI}$ revision; that is, homeowners were asked to estimate what their house would rent for if it were rented to a third party (see BLS 1983). These estimated expenditures were then used as weights in a fixed-weight-type index, where the price relatives that were matched to these weights were market rent price relatives that corresponded to the type of owner-occupied unit. However, Lebow and Rudd $(2003,169)$ noted that these consumer expenditure survey-based estimates of imputed rents in the United States differed from the corresponding BEA estimates for imputed rents, which were based on applying a rent-to-value ratio for rented properties to the owner-occupied stock of housing. Lebow and Rudd (2003) noted that the expenditure survey estimates may be less reliable than the rent-to-value ratio method due to the relatively small size of the consumer expenditure survey, plus the difficulties households may have in recalling or estimating expenditures. ${ }^{13}$ The current BLS procedures for estimating rents for owner-occupied dwellings are different from the pre1998 procedures and are described in Ptacek and Baskin (1996). ${ }^{14}$

There are some problems with the preceding treatment of housing, and they will be discussed in later sections, after the user cost approach to durables has been discussed.

To summarize the previous material, it can be seen that the rental equivalence approach to the treatment of durables is conceptually simple: set the rental equivalence price equal to a current-period rental or leasing price for a comparable product. However, in implementing the approach, many practical difficulties arise. The most important difficulty is that comparable rental markets may not exist, particularly for a unique asset, such as a house. Even if some comparable rental markets exist, there may be difficulties in determining exactly how to choose the comparable rental price for the specific consumer durable at hand.

Note that the rental equivalence approach to pricing the services of a consumer durable is a type of opportunity cost approach; that is, the price for using the services of the durable over the reference period is taken to be the income that is foregone by not leasing or renting the durable. ${ }^{15}$ In the following section, a different type of opportunity cost approach is takennamely, the user cost approach. In this alternative approach, the opportunity

13. Garner et al. (2003) compared the BLS and BEA approaches to the measurement of housing services and found that in 1992, the estimate of dwelling services of renters and owners was about 9 percent higher in the BEA than the BLS. In addition, they found that the two series have consistently grown apart from 1992 to 2000. For additional material on the two approaches, see Heston and Nakamura (2009).

14. For information on current BLS procedure, see Ptacek and Baskin $(1996,34)$. In both the pre- and post-1998 BLS methodologies for $\mathrm{OOH}$, once the $\mathrm{OOH}$ expenditure weights were determined, the weights were multiplied by rental unit price relatives.

15. As will be seen in section 12.9, when a market rental opportunity cost approach is taken to valuing the services of an owned durable, it may be necessary to adjust the comparable market rental price somewhat in order to convert it into a true opportunity cost to the owner. 
cost is essentially taken to be the loss of financial income that the consumer forgoes in tying up his or her capital in the durable good.

\subsection{The User Cost Approach}

The user cost approach to the treatment of durable goods is in some ways very simple: it calculates the cost of purchasing the durable at the beginning of the period, using the services of the durable during the period, then netting off from these costs the benefit that could be obtained by selling the durable at the end of the period, taking into account the interest forgone in tying up one's capital in purchasing the durable. However, there are several details of this procedure that are somewhat controversial. These details involve the treatment of depreciation, interest, and capital gains or holding gains.

Another complication with the user cost approach is that it involves making distinctions between current-period (flow) purchases within the period under consideration and the holdings of physical stocks of the durable at the beginning and the end of the accounting period. Up to this point, all prices and quantity purchases were thought of as taking place at a single point in time, say the middle of the period under consideration, and consumption was thought of as taking place within the period as well. Thus, there was no need to consider the valuation of stocks of consumer durables that households may have at their disposal. The rather complex problems involved in accounting for stocks and flows are unfamiliar to most price statisticians.

To determine the net cost of using the durable good during, say, period 0 , assume that one unit of the durable good is purchased at the beginning of period 0 at the price $P^{0}$. The used or second-hand durable good can be sold at the end of period 0 at the price $P_{S}^{1}$. It might seem that a reasonable net cost for the use of one unit of the consumer durable during period 0 is its initial purchase price $P^{0}$, less its end of period 0 scrap value $P_{S}^{1}$. However, money received at the end of the period is not as valuable as money that is received at the beginning of the period. Thus, in order to convert the end-of-period value into its beginning-of-period equivalent value, it is necessary to discount the term $P_{S}^{1}$ by the term $1+r^{0}$, where $r^{0}$ is the beginning-of-period 0 nominal interest rate that the consumer faces. Hence, the period 0 user cost $u^{0}$ for the consumer durable ${ }^{16}$ is defined as

$$
u^{0} \equiv P^{0}-\frac{P_{S}^{1}}{1+r^{0}} .
$$

There is another way to view the user cost formula in equation (1): the consumer purchases the durable at the beginning of period 0 at the price

16. This approach to the derivation of a user cost formula was used by Diewert (1974), who in turn based it on an approach due to Hicks $(1946,326)$. 
$P^{0}$ and charges himself or herself the rental price $u^{0}$. The remainder of the purchase price, $I^{0}$, defined as

$$
I^{0} \equiv P^{0}-u^{0}
$$

can be regarded as an investment that is to yield the appropriate opportunity cost of capital $r^{0}$ that the consumer faces. At the end of period 0 , this rate of return could be realized, provided that $I^{0}, r^{0}$, and the selling price of the durable at the end of the period $P_{S}^{1}$ satisfy the following equation:

$$
I^{0}\left(1+r^{0}\right)=P_{S}^{1} \text {. }
$$

Given $P_{S}^{1}$ and $r^{0}$, equation (3) determines $I^{0}$, which in turn, given $P^{0}$, determines the user cost $u^{0}$ via equation (2). ${ }^{17}$

Note that user costs are not like the prices of nondurables or services, because the user cost concept involves pricing the durable at $t w o$ points in time rather than at a single point in time. ${ }^{18}$ Because the user cost concept involves prices at two points in time, money received or paid out at the first point in time is more valuable than money paid out or received at the second point in time, so interest rates creep into the user cost formula. Furthermore, because the user cost concept involves prices at two points in time, expected prices can be involved if the user cost is calculated at the beginning of the period under consideration instead of at the end. With all of these complications, it is no wonder many price statisticians would like to avoid using user costs as a pricing concept. However, even for price statisticians who would prefer to use the rental equivalence approach to the treatment of durables over the user cost approach, there is some justification for considering the user cost approach in some detail, because this approach gives insights into the economic determinants of the rental or leasing price of a durable. As will be seen in section 12.9, the user cost for a house can differ substantially for a landlord compared to an owner, and thus adjustments should be made to market rents for dwelling units if these observed rents are to be used as imputations for owner-occupied rents.

The user cost formula in equation (1) can be put into a more familiar form if the period 0 economic depreciation rate $\delta$ and the period 0 ex post asset inflation rate $i^{0}$ are defined. We define $\delta$ as

17. This derivation for the user cost of a consumer durable was also made by Diewert $(1974,504)$.

18. Woolford suggested that interest should be excluded from an ideal price index that measured inflation. In his view, interest is not a contemporaneous price; that is, an interest rate necessarily refers to two points in time: a beginning point, when the capital is loaned, and an ending point, when the capital loaned must be repaid. Thus, if one wanted to restrict attention to a domain of definition that consisted of only contemporaneous prices, interest rates would be excluded. Woolford $(1999,535)$ noted that his ideal inflation measure "would be contemporary in nature, capturing only the current trend in prices associated with transactions in goods and services. It would exclude interest rates on the ground that they are intertemporal prices, representing the relative price of consuming today rather than in the future.” 


$$
(1-\delta) \equiv \frac{P_{S}^{1}}{P^{1}},
$$

where $P_{S}^{1}$ is the price of a used asset at the end of period 0 , and $P^{1}$ is the price of a new asset at the end of period 0 . The period 0 inflation rate for the new asset, $i^{0}$, is defined as

$$
1+i^{0} \equiv \frac{P^{1}}{P^{0}} .
$$

Eliminating $P^{1}$ from equations (4) and (5) leads to the following formula for the end-of-period 0 used-asset price:

$$
P_{S}^{1}=(1-\delta)\left(1+i^{0}\right) P^{0} .
$$

Substitution of equation (6) into equation (1) yields the following expression for the period 0 user cost $u^{0}$ :

$$
u^{0}=\frac{\left[\left(1+r^{0}\right)-(1-\delta)\left(1+i^{0}\right)\right] P^{0}}{1+r^{0}} .
$$

Note that $r^{0}-i^{0}$ can be interpreted as a period 0 real interest rate, and $\delta\left(1+i^{0}\right)$ can be interpreted as an inflation-adjusted depreciation rate.

The user cost $u^{0}$ is expressed in terms of prices that are discounted to the beginning of period 0 . However, it is also possible to express the user cost in terms of prices that are discounted to the end of period $0 .{ }^{19}$ Thus, we define the end-of-period 0 user cost $p^{0}$ as

$$
p^{0} \equiv\left(1+r^{0}\right) u^{0}=\left[\left(1+r^{0}\right)-(1-\delta)\left(1+i^{0}\right)\right] P^{0},
$$

where the last equation follows, using equation (7). If the real interest rate $r^{0 *}$ is defined as the nominal interest rate $r^{0}$, less the asset inflation rate $i^{0}$, and the small term $\delta i^{0}$ is neglected, then the end-of-period user cost defined by equation (8) reduces to

$$
p^{0}=\left(r^{0 *}+\delta\right) P^{0} .
$$

Abstracting from transactions costs and inflation, it can be seen that the end-of-period user cost defined by equation (9) is an approximate rental cost; that is, the rental cost for the use of a consumer (or producer) durable good should equal the (real) opportunity cost of the capital tied up, $r^{0 *} P^{0}$,

19. Thus, the beginning-of-period user cost $u^{0}$ discounts all monetary costs and benefits into their dollar equivalent at the beginning of period 0 , whereas $p^{0}$ accumulates or appreciates all monetary costs and benefits into their dollar equivalent at the end of period 0 . This leaves open how flow transactions that take place within the period should be treated. Following the conventions used in financial accounting suggests that flow transactions taking place within the accounting period be regarded as taking place at the end of the accounting period; hence, following this convention, end-of-period user costs should probably be used by the price statistician. For additional material on beginning- and end-of-period user costs, see Diewert (2005a). 
plus the decline in value of the asset over the period, $\delta P^{0}$. Equations (8) and (9) thus cast some light on the economic determinants of rental or leasing prices for consumer durables.

If the simplified user cost formula defined by equation (9) is used, then forming a price index for the user costs of a durable good is not very much more difficult than forming a price index for the purchase price of the durable good, $P^{0}$. The price statistician needs only to:

- Make a reasonable assumption as to what an appropriate monthly or quarterly real interest rate $r^{0 *}$ should be.

- Make an assumption as to what a reasonable monthly or quarterly depreciation rate $\delta$ should be. ${ }^{20}$

- Collect purchase prices $P^{0}$ for the durable.

- Make an estimate of the total stock of the durable that was held by the reference population during the base period for quantities. In order to construct a superlative index, estimates of the stock held will have to be made for each period.

If it is thought necessary to implement the more complicated user cost formula in equation (8) in place of the simpler formula in equation (9), then the situation is more complicated. As it stands, the end-of-period user cost formula in equation (8) is an ex post (after the fact) user cost: the asset inflation rate $i^{0}$ cannot be calculated until the end of period 0 has been reached. Equation (8) can be converted into an ex ante (before the fact) user cost formula if $i^{0}$ is interpreted as an anticipated asset inflation rate. The resulting formula should approximate a market rental rate for the asset under inflationary conditions. ${ }^{21}$ However, in section 12.11 , it will be seen that this approximate equality is indeed only an approximate one.

Note that in the user cost approach to the treatment of consumer durables, the entire user cost formula in equation (8) or (9) is the period 0 price. Thus, in the time-series context, it is not necessary to deflate each component of the formula separately; the period 0 price, $p^{0} \equiv\left[r^{0}-i^{0}+\delta\left(1+i^{0}\right)\right] P^{0}$, is compared to the corresponding period 1 price, $p^{1} \equiv\left[r^{1}-i^{1}+\delta\left(1+i^{1}\right)\right] P^{1}$, and so on.

20. The geometric model for depreciation requires only a single monthly or quarterly depreciation rate. Other models of depreciation may require the estimation of a sequence of vintage depreciation rates. If the estimated annual geometric depreciation rate is $\delta_{a}$, then the corresponding monthly geometric depreciation rate $\delta$ can be obtained by solving the equation $(1-\delta)^{12}=1-\delta_{a}$. Similarly, if the estimated annual real interest rate is $r_{a}^{*}$, then the corresponding monthly real interest rate $r^{*}$ can be obtained by solving the equation $\left(1+r^{*}\right)^{12}=1+r_{a}^{*}$.

21. Because landlords must set their rent at the beginning of the period (and in fact, they usually set their rent for an extended period of time), if the user cost approach is used to model the economic determinants of market rental rates, then the asset inflation rate $i^{0}$ should be interpreted as an expected inflation rate rather than an after-the-fact actual inflation rate. This use of ex ante prices in this price measurement context should be contrasted with the preference of national accountants to use actual or ex post prices in the SNA. 
Here is a list of some of the problems and difficulties that might arise in implementing a user cost approach to purchases of a consumer durable: ${ }^{22}$

- It is difficult to determine what the relevant nominal interest rate $r^{0}$ is for each household. If a consumer has to borrow to finance the cost of a durable good purchase, then this interest rate will typically be much higher than the safe rate of return that would be the appropriate opportunity cost rate of return for a consumer who had no need to borrow funds to finance the purchase. ${ }^{23}$ It may be necessary to simply use a benchmark interest rate that would be determined by either the government, a national statistical agency, or an accounting standards board.

- It will generally be difficult to determine what the relevant depreciation rate is for the consumer durable. ${ }^{24}$

- Ex post user costs based on the formula in equation (8) will be too volatile to be acceptable to users ${ }^{25}$ (due to the volatility of the asset inflation rate $i^{0}$ ), and hence an ex ante user cost concept will have to be used. This creates difficulties, in that different national statistical agencies will generally make different assumptions and use different methods in order to construct forecasted structures and land inflation rates; hence, the resulting ex ante user costs of the durable may not be comparable across countries. ${ }^{26}$

- The user cost formula in equation (8) should be generalized to accom-

22. For additional material on difficulties with the user cost approach, see Diewert (1980, 475-9; 2005a) and Katz (1983, 415-22).

23. Katz $(1983,415-6)$ comments on the difficulties involved in determining the appropriate rate of interest to use: "There are numerous alternatives: a rate on financial borrowings, on savings, and a weighted average of the two; a rate on nonfinancial investments. e.g., residential housing, perhaps adjusted for capital gains; and the consumer's subjective rate of time preference. Furthermore, there is some controversy about whether it should be the maximum observed rate, the average observed rate, or the rate of return earned on investments that have the same degree of risk and liquidity as the durables whose services are being valued."

24. It is not necessary to assume declining-balance depreciation in the user cost approach: any pattern of depreciation can be accommodated, including one-hoss shay depreciation, where the durable yields a constant stream of services over time until it is scrapped. See Diewert and Lawrence (2000) for some empirical examples of Canada using different assumptions about the form of depreciation. For references to the depreciation literature and for empirical methods for estimating depreciation rates, see Hulten and Wykoff (1981a, 1981b, 1996) and Jorgenson (1996).

25. Goodhart (2001, F351) comments on the practical difficulties of using ex post user costs for housing as follows: "An even more theoretical user cost approach is to measure the cost foregone by living in an owner occupied property as compared with selling it at the beginning of the period and repurchasing it at the end. . . . But this gives the absurd result that as house prices rise, so the opportunity cost falls; indeed the more virulent the inflation of housing asset prices, the more negative would this measure become. Although it has some academic aficionados, this flies in the face of common sense; I am glad to say that no country has adopted this method." As will be seen later, Iceland has in fact adopted a simplified user cost framework.

26. For additional material on the difficulties involved in constructing ex ante user costs, see Diewert (1980, 475-86) and Katz (1983, 419-20). For empirical comparisons of different user cost formulae, see Harper, Berndt, and Wood (1989) and Diewert and Lawrence (2000). 
modate various taxes that may be associated with the purchase of a durable or with the continuing use of the durable. ${ }^{27}$

\subsection{Unique Durable Goods and the User Cost Approach}

In the previous section, it was assumed that a newly produced unit of the durable good remained the same from period to period. This means that the various vintages of the durable good repeat themselves from period to period, and hence a particular vintage of the good in the current period can be compared with the same vintage in the next period. In particular, consider the period 0 user cost of a new unit of a durable good $p_{0}^{0}$, defined earlier by equation (8). Recall that $P^{0}$ is the beginning of period 0 purchase price for the durable, $r^{0}$ is the nominal opportunity cost of capital that the household faces in period $0, i^{0}$ is the anticipated period 0 inflation rate for the durable good, and $\delta_{0}$ is the one-period depreciation rate for a new unit of the durable good. In previous sections, it was assumed that the period 0 user cost $p_{0}^{0}$ for a new unit of the durable could be compared with the corresponding period 1 user $\operatorname{cost} p_{0}^{1}$ for a new unit of the durable purchased in period 1 . This period 1 user cost can be defined as follows:

$$
p_{0}^{1}=\left[\left(1+r^{1}\right)-\left(1-\delta_{0}\right)\left(1+i^{1}\right)\right] P^{1}=\left[r^{1}-i^{1}+\delta_{0}\left(1+i^{1}\right)\right] P^{1} .
$$

However, many durable goods are produced as one-of-a-kind models. For example, a new house may have many features that are specific to that particular house. An exact duplicate of it is unlikely to be built in the following period. Thus, if the user cost for the house is constructed for period 0 using the formula in equation (8), where the new house price $P^{0}$ plays a key role, then because there will not necessarily be a comparable new house price for the same type of unit in period 1, it will not be possible to construct the period 1 user cost for a house of the same type, $p_{0}^{1}$, defined by equation (10), because the comparable new house price $P^{1}$ will not be available.

Let $P_{v}^{t}$ be the second-hand market price at the beginning of period $t$ of a unit of a durable good that is $v$ periods old. Define $\delta_{v}$ to be the depreciation rate for a unit of the durable good that is $v$ periods old at the beginning of the period under consideration. Using this notation, the user cost of the house (which is now one period old) for period $1, p_{1}^{1}$, can be defined as

27. For example, property taxes are associated with the use of housing services and hence should be included in the user cost formula; see section 12.8.2. As Katz $(1983,418)$ noted, taxation issues also impact the choice of the interest rate: "Should the rate of return be a before or after tax rate?" From the viewpoint of a household that is not borrowing to finance the purchase of the durable, an after-tax rate of return seems appropriate, but from the point of a leasing firm, a before-tax rate of return seems appropriate. This difference helps to explain why rental equivalence prices for the durable might be higher than user cost prices; see also section 12.9.4. 


$$
p_{1}^{1} \equiv\left(1+r^{1}\right) P_{1}^{1}-\left(1-\delta_{1}\right)\left(1+i^{1}\right) P_{1}^{1},
$$

where $P_{1}^{1}$ is the beginning-of-period 1 price for the house that is now one period old, $r^{1}$ is the nominal opportunity cost of capital that the household faces in period $1, i^{1}$ is the anticipated period 1 inflation rate for the durable good, and $\delta_{1}$ is the one-period depreciation rate for a house that is one period old. For a unique durable good, there is no beginning-of-period 1 price for a new unit of the durable, $P^{1}$, but it is natural to impute this price as the potentially observable market price for the used durable, $P_{1}^{1}$, divided by one, minus the period 0 depreciation rate, $\delta_{0}$; that is, we define an imputed period 1 price for a new unit of the unique durable as follows:

$$
P^{1} \equiv \frac{P_{1}^{1}}{1-\delta_{0}} .
$$

If equation (12) is solved for $P_{1}^{1}$ and the solution is substituted into the user cost defined by equation (11), then the following expression is obtained for $p_{1}^{1}$, the period 1 user cost of a one-period-old unique consumer durable:

$$
p_{1}^{1} \equiv\left(1-\delta_{0}\right)\left[\left(1+r^{1}\right)-\left(1-\delta_{1}\right)\left(1+i^{1}\right)\right] P^{1} .
$$

If it is further assumed that the unique consumer durable follows the geometric model of depreciation, then $\delta_{0}$ equals $\delta_{1}$, and setting both of these depreciation rates equal to a common rate, say $\delta$, leads to the following relationship between the imputed rental cost in period 1 of a new unit of the consumer durable, $p_{0}^{1}$ and the period 1 user cost of the one-period-old consumer durable, $p_{1}^{1}$ :

$$
p_{1}^{0}=\frac{p_{1}^{1}}{1-\delta} .
$$

Thus, in order to obtain an imputed rental price for the unique consumer durable for period $1, p_{0}^{1}$, that is comparable to the period 0 rental price for a new unit of the consumer durable, $p_{0}^{0}$, it is necessary to make a quality adjustment to the period 1 rental price for the one-period-old durable, $p_{1}^{1}$, by dividing this latter price by one, minus the one-period geometric depreciation rate, $\delta$. This observation has implications for the quality adjustment of observed market rents of houses. Without this type of quality adjustment, observed dwelling unit rents will have a downward bias, because the observed rents do not adjust for the gradual lowering of the quality of the unit due to depreciation of the unit..$^{28}$

28. There is an exception to this general observation: if housing depreciation is of the onehoss shay type, then there is no need to quality adjust observed rents for the same unit over time. However, one-hoss shay depreciation is empirically unlikely in the housing market, because renters are generally willing to pay a rent premium for a new unit over an older unit of the same type. For empirical evidence of this age premium, see Malpezzi, Ozanne, and Thibodeau (1987, $378)$ and Hoffman and Kurz $(2002,19)$. 
Note also that in order to obtain an imputed purchase price for the unique consumer durable for period $1, P^{1}$, that is comparable to the period 0 purchase price for a new unit of the consumer durable, $P^{0}$, it is necessary to make a quality adjustment to the period 1 used-asset price for the oneperiod-old durable, $P_{1}^{1}$, by dividing this latter price by one, minus the period 0 depreciation rate, $\delta_{0}{ }^{29}$

This section is concluded with some observations on the difficulties for economic measurement that occur when it is attempted to determine depreciation rates empirically for unique assets. Consider again equation (12), which allows one to express the potentially observable market price of the unique asset at the beginning of period $1, P_{1}^{1}$, as being equal to $\left(1-\delta_{0}\right) P^{1}$, where $P^{1}$ is a hypothetical period 1 price for a new unit of the unique asset. If it is assumed that this hypothetical period 1 new asset price is equal to the period 0 -to-1 inflation rate factor $\left(1+i^{0}\right)$ multiplied by the observable period 0 asset price, $P^{0}$, then the following relationship between the two observable asset prices is obtained:

$$
P_{1}^{1}=\left(1-\delta_{0}\right)\left(1+i^{0}\right) P^{0} .
$$

Thus, the potentially observable period 1 used-asset price $P_{1}^{1}$ is equal to the period 0 new asset price $P^{0}$ multiplied by the product of two factors: $\left(1-\delta_{0}\right)$, a quality-adjustment factor that takes into account the effects of aging on the unique asset, and $\left(1+i^{0}\right)$, a period-to-period pure price change factor, holding quality constant. The problem with unique assets is that cross-sectional information on used-asset prices at any point in time is no longer available to enable one to sort out the separate effects of these two factors. Thus, there is a fundamental identification problem with unique assets; without extra information or assumptions, it will be impossible to distinguish the separate effects of asset deterioration and asset inflation. ${ }^{30}$ In practice, this identification problem is solved by making somewhat arbitrary assumptions about the form of depreciation that the asset is expected to experience. For example, if the unique asset is a painting by a master artist, then the depreciation rate can be assumed to be very close to zero. As a final example of how assumptions replace detailed knowledge about second-hand prices for all vintages of a unique durable good, we could implement a household

29. This type of quality adjustment to the asset prices for unique consumer durables will always be necessary; that is, there is no exception to this rule, as was the case for one-hoss shay depreciation in the context of quality-adjusting rental prices.

30. Special cases of this fundamental identification problem have been noted in the context of various econometric housing models: "For some purposes one might want to adjust the price index for depreciation. Unfortunately, a depreciation adjustment cannot be readily estimated along with the price index using our regression method. . . . In applying our method, therefore, additional information would be needed in order to adjust the price index for depreciation" (Bailey, Muth, and Nourse 1963,936). "The price index and depreciation are perfectly collinear, so if one cares about the price index, it is necessary to use external information on the geometric depreciation rate of houses" (Palmquist 2006, 43). 
retirement survey for these types of unique assets. The survey could ask the following questions:

- When was the asset purchased?

- What was the purchase price?

- When was the asset sold or scrapped?

- If sold, what was the selling price?

The preceding information is not sufficient to determine depreciation rates for the unique asset. In addition to the preceding information, we will have to make some additional assumptions:

- The form of depreciation across periods would have to be determined by assumption; that is, is depreciation of the one-hoss shay, straight line, or geometric type?

- It will be necessary to assume that the price of a hypothetical new unique asset is proportional to a known price index.

Armed with this information, it is possible to determine depreciation rates for the unique asset and hence to form user costs for these assets.

The problems associated with determining user costs for unique assets for businesses are not as severe as the corresponding problems for households. For example, if we want to construct user costs for business structures, this can be done, because businesses normally have asset registers and have information on the time of purchase and sale along with the purchase and sale price. This information could be accessed in investment surveys that also ask questions about asset sales and retirements. Canada, ${ }^{31}$ the Netherlands, ${ }^{32}$ and New Zealand ask such questions on retirements in their investment surveys, and Japan is following suit. ${ }^{33}$ Diewert and Wykoff (2007) indicate how this type of survey can be used to obtain estimates for depreciation rates.

Housing is the primary example of a unique asset. In addition to the problems outlined in this section, there are other major problems associated with this particular form of unique asset. These problems will be discussed in the following sections.

\subsection{The User Cost of Owner-Occupied Housing}

Owner-occupied housing is typically an example of a unique consumer durable, so the material on the quality adjustment of both stock and rental

31. For a description and further references to the Canadian program on estimating depreciation rates, see Baldwin et al. (2005) and Statistics Canada (2007).

32. Actually, since 1991, the Dutch have a separate (mail) survey for enterprises with more than one hundred employees to collect information on discards and retirements, called the Survey on Discards; see Bergen et al. $(2005,8)$ for a description of the Dutch methods.

33. The Economic and Social Research Institute (ESRI), Cabinet Office of Japan, with the help of Koji Nomura, has implemented a new investment survey that asks questions on retirements. 
prices developed in the previous section applies to this commodity. However, owner-occupied housing is also an example of a composite good; that is, two distinct commodities are bundled together and sold (or rented) at a single price. The two distinct commodities are the structure and the land that the structure sits on.

The decomposition of housing into structures and land components is important for the SNA, because these two components are treated very differently in the SNA. To model this composite-good situation, consider a particular newly constructed dwelling unit that is purchased at the beginning of period 0 . Suppose that the purchase price is $V^{0}$. This value can be regarded as the sum of (a) a cost of producing the structure, $P_{S}^{0} Q_{S}^{0}$, where $Q_{S}^{0}$ is the number of square meters of floor space in the structure, and $P_{S}^{0}$ is the beginning-of-period 0 price of construction per square meter; and (b) the cost of the land, $P_{L}^{0} Q_{L}^{0}$, where $Q_{L}^{0}$ is the number of square meters of the land that the structure sits on and the associated yard, and $P_{L}^{0}$ is the beginningof-period 0 price of the land per square meter. ${ }^{34}$ Thus, at the beginning of period 0 , the value of the dwelling unit is $V^{0}$, defined as follows:

$$
V^{0}=P_{S}^{0} Q_{S}^{0}+P_{L}^{0} Q_{L}^{0} \text {. }
$$

Suppose that the anticipated price of a unit of a new structure at the beginning of period 1 is $P_{S}^{1 a}$ and that the anticipated price of a unit of land at the beginning of period 1 is $P_{L}^{1 a}$. We define the period 0 anticipated inflation rates for new structures and land, $i_{s}^{0}$ and $i_{L}^{0}$, respectively, as follows:

$$
\begin{aligned}
& 1+i_{S}^{0} \equiv \frac{P_{S}^{1 a}}{P_{S}^{0}} ; \\
& 1+i_{L}^{0} \equiv \frac{P_{L}^{1 a}}{P_{L}^{0}} .
\end{aligned}
$$

Let $\delta_{0}$ be the period 0 depreciation rate for the structure. Then, the anticipated beginning-of-period 1 value for the structure and the associated land is equal to

$$
V^{1 a}=P_{S}^{1 a}\left(1-\delta_{0}\right) Q_{S}^{0}+P_{L}^{1 a} Q_{L}^{0} .
$$

Note the presence of the depreciation term $\left(1-\delta_{0}\right)$ on the right-hand side of equation (19). Should this term be associated with the expected beginning-of-period 1 price for a new unit of structures $P_{S}^{1 a}$ or with the structures quantity term $Q_{S}^{0}$ ? On the principle that like should be compared to like for prices, it seems preferable to associate $\left(1-\delta_{0}\right)$ with the quantity term $Q_{S}^{0}$. This is consistent with the treatment of unique assets that was suggested in the previous section; that is, the initial quantity of structures 
$Q_{S}{ }^{0}$ should be quality adjusted downward to the amount $\left(1-\delta_{0}\right) Q_{S}^{0}$ at the beginning of period 1 .

Now, we calculate the cost (including the imputed opportunity cost of capital $r^{0}$ ) of buying the dwelling unit at the beginning of period 0 and (hypothetically) selling it at the end of period 0 . The following end-of-period 0 user cost or imputed rental cost $R^{0}$ for the dwelling unit is obtained using equations (16) through (19):

$$
\begin{aligned}
R^{0} & \equiv V^{0}\left(1+r^{0}\right)-V^{1 a} \\
& =\left[P_{S}^{0} Q_{S}^{0}+P_{L}^{0} Q_{L}^{0}\right]\left(1+r^{0}\right)-\left[P_{S}^{1 a}\left(1-\delta_{0}\right) Q_{S}^{0}+P_{L}^{1 a} Q_{L}^{0}\right] \\
& =\left[P_{S}^{0} Q_{S}^{0}+P_{L}^{0} Q_{L}^{0}\right]\left(1+r^{0}\right)-\left[P_{S}^{0}\left(1+i_{S}^{0}\right)\left(1-\delta_{0}\right) Q_{S}^{0}+P_{L}^{0}\left(1+i_{L}^{0}\right) Q_{L}^{0}\right] \\
& =p_{S}^{0} Q_{S}^{0}+p_{L}^{0} Q_{L}^{0},
\end{aligned}
$$

where separate period 0 user costs of structures and land, $p_{S}{ }^{0}$ and $p_{L}{ }^{0}$, are defined as follows:

$$
\begin{aligned}
& p_{S}^{0}=\left[\left(1+r^{0}\right)-\left(1+i_{S}^{0}\right)\left(1-\delta_{0}\right)\right] P_{S}^{0}=\left[r^{0}-i_{S}^{0}+\delta_{0}\left(1+i_{S}^{0}\right)\right] P_{S}^{0} \\
& p_{L}^{0}=\left[\left(1+r^{0}\right)-\left(1+i_{L}^{0}\right)\right] P_{L}^{0}=\left[r^{0}-i_{L}^{0}\right] P_{L}^{0}
\end{aligned}
$$

Note that the preceding algebra indicates some of the major determinants of market rents for rental properties. ${ }^{35}$ The user cost formulae defined by equations (21) and (22) can be further simplified if the same approximations that were made in section 12.4 are made here (recall equation [9]); that is, assume that the terms $r^{0}-i_{S}^{0}$ and $r^{0}-i_{L}^{0}$ can be approximated by a real interest rate $r^{0 *}$, and neglect the small term $\delta_{0}$ multiplied by $i_{S}^{0}$ in equation (21). Then, the user costs defined by equations (21) and (22) simplify to:

$$
\begin{aligned}
& p_{S}^{0}=\left[\left(r^{0 *}+\delta_{0}\right)\right] P_{S}^{0} ; \\
& p_{L}^{0}=r^{0 *} P_{L}^{0} .
\end{aligned}
$$

Thus, the imputed rent for an owner-occupied dwelling unit is made up of three main costs:

- The real opportunity cost of the financial capital tied up in the structure

- The real opportunity cost of the financial capital tied up in the land

- The depreciation cost of the structure

This simplified approach to the user cost of housing can be even further simplified by assuming that the ratio of the quantity of land to structures is fixed, so the aggregate user cost of housing is equal to $\left[r^{0 *}+\delta\right] P_{H}^{0}$, where $P_{H}$ is a quality-adjusted housing price index that is based on all properties sold

35. Looking at equation (22), it can be seen that the land user cost defined by this equation could be negative if the anticipated rate of land price appreciation, $i_{L}^{0}$, is greater than the beginning of the period opportunity cost of capital, $r^{0}$. We will discuss possible solutions to this complication in section 12.11 . 
in the country to households during the period under consideration, and $\delta$ is a geometric depreciation rate that applies to the composite of household structures and land. This super-simplified approach is used by Iceland (see Gudnason [2003, 28-29] and Gudnason and Jónsdóttir [2009]). ${ }^{36}$ A variant of this approach is used by the BEA: Lebow and Rudd $(2003,168)$ note that the U.S. national accounts imputation for the services of owner-occupied housing is obtained by applying rent-to-value ratios for tenant-occupied housing to the stock of owner-occupied housing. The rent-to-value ratio can be regarded as an estimate of the applicable real interest rate plus the depreciation rate.

Now, we can calculate the cost (including the imputed opportunity cost of capital $r^{1}$ ) of buying the used dwelling unit at the beginning of period 1 and (hypothetically) selling it at the end of period 1 . Thus, at the beginning of period 1 , the value of the depreciated dwelling unit is $V^{1}$, defined as

$$
V^{1}=P_{S}^{1}\left(1-\delta_{0}\right) Q_{S}^{0}+P_{L}^{1} Q_{L}^{0},
$$

where $P_{S}^{1}$ is the beginning-of-period 1 construction price for building a new dwelling unit of the same type, and $P_{L}^{1}$ is the beginning-of-period 1 price of land for the dwelling unit. Note that equation (25) is an end-of-period 0 ex post or actual value of the dwelling unit, whereas the similar expression in equation (19) defined a beginning-of-period 0 ex ante or anticipated value of the dwelling unit at the end of period 0 or the beginning of period 1 .

Suppose that the anticipated price of a unit of a new structure at the beginning of period 2 is $P_{S}^{2 a}$ and that the anticipated price of a unit of land at the beginning of period 2 is $P_{L}^{2 a}$. We define the period 1 anticipated inflation rates for new structures and land, $i_{S}^{1}$ and $i_{L}^{1}$, respectively, as follows:

$$
\begin{aligned}
& 1+i_{S}^{1} \equiv \frac{P_{S}^{2 a}}{P_{S}^{1}} \\
& 1+i_{L}^{1} \equiv \frac{P_{L}^{2 a}}{P_{L}^{1}} .
\end{aligned}
$$

Let $\delta_{1}$ be the period 1 depreciation rate for the structure. Then, the anticipated beginning-of-period 2 value for the structure and the associated land is equal to

$$
V^{2 a}=P_{S}^{2 a}\left(1-\delta_{0}\right)\left(1-\delta_{1}\right) Q_{S}^{0}+P_{L}^{2 a} Q_{L}^{0} .
$$

36. The real interest rate that is used is approximately 4 percent per year, and the combined depreciation rate for land and structures is assumed to equal 1.25 percent per year. The depreciation rate for structures alone is estimated to be 1.5 percent per year. Property taxes are accounted for separately in the Icelandic CPI. Housing price information is provided by the State Evaluation Board (SEB) based on property sales data of both new and old housing. The SEB also estimates the value of the housing stock and land in Iceland, using a hedonic regression model based on property sales data. The value of each household's dwelling is collected in the Household Budget Survey. 
The following end-of-period 1 user cost or imputed rental cost $R_{1}^{1}$ for a oneperiod-old dwelling unit is obtained using equations (25) through (28):

$$
\begin{aligned}
R_{1}^{1} \equiv & V^{1}\left(1+r^{1}\right)-V^{2 a} \\
= & {\left[P_{S}^{1}\left(1-\delta_{0}\right) Q_{S}^{0}+P_{L}^{1} Q_{L}^{0}\right]\left(1+r^{1}\right) } \\
& -\left[P_{S}^{2 a}\left(1-\delta_{0}\right)\left(1-\delta_{1}\right) Q_{S}^{0}+P_{L}^{2 a} Q_{L}^{0}\right] \\
= & {\left[P_{S}^{1}\left(1-\delta_{0}\right) Q_{S}^{0}+P_{L}^{1} Q_{L}^{0}\right]\left(1+r^{1}\right) } \\
& -\left[P_{S}^{1}\left(1+i_{S}^{1}\right)\left(1-\delta_{0}\right)\left(1-\delta_{1}\right) Q_{S}^{0}+P_{L}^{1}\left(1+i_{L}^{1}\right) Q_{L}^{0}\right] \\
= & p_{S}^{1}\left(1-\delta_{0}\right) Q_{S}^{0}+p_{L}^{1} Q_{L}^{0},
\end{aligned}
$$

where the period 1 user costs of one-period-old structures and land, $p_{S 1}^{1}$ and $p_{L}^{1}$, are defined as follows:

$$
\begin{aligned}
& p_{S}^{1}=\left[\left(1+r^{1}\right)-\left(1+i_{S}^{1}\right)\left(1-\delta_{1}\right)\right] P_{S}^{1}=\left[r^{1}-i_{S}^{1}+\delta_{1}\left(1+i_{S}^{1}\right)\right] P_{S}^{1} \\
& p_{L}^{1}=\left[\left(1+r^{1}\right)-\left(1+i_{L}^{1}\right)\right] P_{L}^{1}=\left[r^{1}-i_{L}^{1}\right] P_{L}^{1} .
\end{aligned}
$$

Now compare the end-of-period 0 imputed rent $R^{0}$ for the structure and the underlying land, defined by equation (20), and the associated period 0 user costs of structures and land $\left(p_{S}^{0}\right.$ and $p_{L}^{0}$, defined by equations [21] and [22]), with the corresponding end-of-period 1 imputed rent $R_{1}^{1}$ for the one period older structure and the underlying land, defined by equation (29), and the associated period 1 user costs of structures and land $\left(p_{S}^{1}\right.$ and $p_{L}^{1}$, defined by equations [30] and [31]). These period 0 and period 1 user costs are comparable and can be used in price indexes. Also, the period 0 and period 1 quantity of land is the constant amount of land, $Q_{L}^{0}$, and this is also comparable and can be used as a weighting factor for the user cost of land in a price index. The only tricky aspect to note is that in order to make the structures quantity comparable for price index purposes, the period 1 quantity of structures associated with the dwelling unit under consideration should be set equal to $\left(1-\delta_{0}\right) Q_{S}^{0}$, rather than leaving it at the period 0 level, $Q_{S}^{0}$. This is the same point that was made in the previous section, but in this section, the complications due to the fact that housing services are a mixture of structure and land services are taken into account.

It is evident that the main drivers for the user costs of structures and land are a price index for new dwelling construction, $P_{S}^{t}$, and a price index for residential land, $P_{L}^{t}$. Most statistical agencies have a constant-quality price index for new residential structures, because this index is required in the national accounts in order to deflate investment expenditures on residential structures. This index could be used as an approximation to $P_{S}^{t .}{ }^{37}$ The national accounts also require an imputation for the services of owneroccupied housing, and thus the constant-quality price component of this

37. This index may only be an approximation, because it covers the construction of rental properties as well as owner-occupied dwellings. 
imputation may be suitable for Consumer Price Index purposes. ${ }^{38}$ If the national accounts division also computes quarterly real balance sheets for the economy, then a price index for residential land may be available to the prices division. However, even if this is the case, there will be problems in producing this price index for land on a timely basis and at a monthly frequency. ${ }^{39}$ Another possible source of information on land prices may be found in land title registry offices and in the records of real estate firms.

In the following section, the problems involved in obtaining a constantquality price index for the asset value (or stock value) of a housing unit are examined in a bit more detail. Recall that this type of index is required for both the acquisitions and user cost approaches (and it may be required for the rental equivalence approach as well, if imputed rents are constructed using the rent-to-value ratio method used by the BEA).

\subsection{The Empirical Estimation of Housing Price Indexes}

There are three broad approaches ${ }^{40}$ to constructing constant-quality price indexes for the purchase price of a housing unit: the repeat sales approach, the stratification approach, and the hedonic regression approach.

These approaches will be discussed next. The hedonic regression approach can also be applied to the problem of constructing constant-quality indexes of rent.

\subsubsection{The Repeat Sales Approach}

The repeat sales approach is due to Bailey, Muth, and Nourse (1963), who saw their procedure as a generalization of the chained matched-model methodology that was used by the early pioneers in the construction of real estate price indexes, such as Wyngarden (1927) and Wenzlick (1952). We will not describe the technical details of the method, but note that the method uses information on properties that trade on the market more than once over the sample period. ${ }^{41}$ By utilizing information on identical properties that trade

38. However, the national accounts imputation for the services of $\mathrm{OOH}$ will only be produced on a quarterly basis, so some additional work will be required to produce a price deflator on a monthly basis. Also, even though the SNA recommends that the imputation for the services of $\mathrm{OOH}$ be based on the rental equivalent method, it may be the case that the imputation covers only the imputed depreciation on the structures part of $\mathrm{OOH}$. As was pointed out earlier, there are two other important additional components that should also be included in OOH services: namely, the imputed real interest on the structures and the land on which the structures sit. These latter two components of imputed expenditures are likely to be considerably larger than the depreciation component.

39. Another source of information on the value of residential land may be available from the local property tax authorities, particularly if properties are assessed at market values.

40. These approaches are discussed in more detail in Diewert (2009).

41. See Case and Shiller (1989) and Diewert (2003c, 31-39) for detailed technical descriptions of the method. Diewert showed how the repeat sales method is related to Summers' (1973) country product dummy model used in international price comparisons and the product dummy variable hedonic regression model proposed by Aizcorbe, Corrado, and Doms (2001). 
more than one period, the repeat sales method attempts to hold the quality of the properties constant over time.

We now discuss some of the advantages and disadvantages of the repeat sales method..$^{42}$ The main advantages of the repeat sales model are as follows:

- Source data is available from administrative records on the resale of the same property, so no imputations are involved.

- The results are reproducible; that is, different statisticians who are given the same data on the sales of housing units will come up with the same estimate of quality-adjusted price change. ${ }^{43}$

The main disadvantages of the repeat sales model are as follows:

- It does not use all of the available information on property sales; it uses only information on units that have sold more than once during the sample period.

- It cannot deal adequately with depreciation of the dwelling unit or structure.

- It cannot deal adequately with units that have undergone major repairs or renovations. ${ }^{44}$ Conversely, a general hedonic regression model for housing or structures can adjust for the effects of renovations and extensions if (real) expenditures on renovations and extensions are known at the time of sale (or rental). ${ }^{45}$

42. Throughout this section, we will discuss the relative merits of the different methods that have been suggested for constructing property price indexes. For a similar discussion, see Hoffmann and Lorenz (2006, 2-6).

43. Hedonic regression models suffer from a reproducibility problem; that is, different statisticians will use different characteristics variables, will use different functional forms, and will make different stochastic specifications, possibly leading to quite different results. However, the repeat sales model is not as reproducible in practice as indicated in the main text, because in some variants of the method, houses that are flipped (sold very rapidly) and houses that have not sold for long periods are excluded from the regressions. The exact method for excluding these observations may vary from time to time, leading to a lack of reproducibility.

44. Case and Shiller (1989) used a variant of the repeat sales method using U.S. data on house sales in four major cities over the years 1970 to 1986 . They attempted to deal with the depreciation and renovation problems as follows: "The tapes contain actual sales prices and other information about the homes. We extracted from the tapes for each city a file of data on houses sold twice for which there was no apparent quality change and for which conventional mortgages applied" (Case and Shiller 1989, 125-6). It is sometimes argued that renovations are approximately equal to depreciation. While this may be true in the aggregate, it certainly is not true for individual dwelling units, because over time, many units are demolished.

45. However, usually information on maintenance and renovation expenditures is not available in the context of estimating a hedonic regression model for housing. Malpezzi, Ozanne, and Thibodeau (1987, 375-6) comment on this problem as follows: "If all units are identically constructed, inflation is absent, and the rate of maintenance and repair expenditures is the same for all units, then precise measurement of the rate of depreciation is possible by observing the value or rent of two or more units of different ages. . . To accurately estimate the effects of aging on values and rents, it is necessary to control for inflation, quality differences in housing 
- The method cannot be used if indexes are required for very fine classifications of the type of property due to a lack of observations. In particular, if monthly property price indexes are required, the method may fail due to a lack of market sales for smaller categories of property.

- In principle, estimates for past price change obtained by the repeat sales method should be updated as new transaction information becomes available. Thus, the repeat sales property price index may be subject to never-ending revision.

We turn now to another class of methods used to form constant-quality property price indexes.

\subsubsection{Stratification Methods}

Possibly the simplest approach to the construction of a property price index is to stratify or decompose the market into separate types of property, calculate the mean (or more commonly, the median) price for all properties transacted in that cell for the current period and the base period, and then use the ratio of the means as a real estate price index.

The problem with this method can be explained as follows: if there are too many cells in the stratification, then there may not be a sufficient number of transactions in any given period in order to form an accurate cell average price, but if there are too few cells in the stratification, then the resulting cell averages will suffer from unit-value bias; that is, the mix of properties sold in each period within each cell may change dramatically from period to period, and thus the resulting stratified indexes do not hold quality constant.

The stratification method can work well; for example, see Gudnason and Jónsdóttir (2007, 3-5), where they note that they work with some eight thousand to ten thousand real estate transactions per year in Iceland, which is a sufficient number of observations to be able to produce thirty monthly subindexes.

The Australian Bureau of Statistics ${ }^{46}$ (ABS) is also experimenting with stratification techniques in order to produce constant-quality housing price indexes. The ABS clustering procedures are very interesting and novel, but one must be a bit cautious in interpreting the resulting price changes, because any individual suburb might contain a mixture of properties, and thus the resulting indexes may be subject to a certain amount of unit-value bias. ${ }^{47}$ The main advantages of the stratification method are as follows:

units, and location. The hedonic technique controls for differences in dwelling quality and inflation rates but cannot control for most differences in maintenance (except to the extent that they are correlated with location)."

46. See Branson (2006).

47. However, Prasad and Richards (2006) show that the stratification method applied to Australian house price data gave virtually the same results as a hedonic model that had locational explanatory variables. 
- The method is conceptually acceptable, but it depends crucially on the choice of stratification variables.

- The method is reproducible, conditional on an agreed list of stratification variables.

- Housing price indexes can be constructed for different types and locations of housing.

- The method is relatively easy to explain to users.

The main disadvantages of the stratification method are as follows:

- The method cannot deal adequately with depreciation of the dwelling units or structures.

- The method cannot deal adequately with units that have undergone major repairs or renovations.

- The method requires some information on housing characteristics, so sales transactions can be allocated to the correct cell in the classification scheme. ${ }^{48}$

- If the classification scheme is very coarse, then there may be some unitvalue bias in the indexes.

- If the classification scheme is very fine, the detailed cell indexes may be subject to a considerable amount of sampling variability due to small sample sizes.

- The method cannot decompose a property price index into structure and land components.

My overall evaluation of the stratification method is that it can be quite satisfactory, if an appropriate level of detail is chosen for the number of cells, the index is adjusted using other information for depreciation and renovations bias, and a decomposition of the index into structure and land components is not required.

It is well known that stratification methods can be regarded as special cases of general hedonic regressions, ${ }^{49}$ so we now turn to this more general technique.

\subsubsection{Hedonic Methods}

Although there are several variants of the hedonic regression technique, the basic model regresses the logarithm of the sale price of the property on the price-determining characteristics of the property, and a time dummy variable is added for each period in the regression (except the base period). ${ }^{50}$

48. If no information on housing characteristics is used, then the method is subject to tremendous unit-value bias.

49. See Diewert (2003a), who showed that stratification techniques or the use of dummy variables can be viewed as a nonparametric regression technique.

50. The main features of a general hedonic regression model were laid out in Court (1939). This publication was not readily available to researchers, so the technique was not used widely until the work of Griliches (1971a, 1971b) popularized the technique. For a recent survey of 
Once the estimation has been completed, these time dummy coefficients can be exponentiated and turned into an index. ${ }^{51}$

Because the method assumes that information on the characteristics of the properties sold is available, the data can be stratified, and a separate regression can be run for each important class of property. Thus, the hedonic regression method can be used to produce a family of indexes. ${ }^{52}$

The issues associated with running weighted hedonic regressions are rather subtle, and the recent literature on this topic will not be reviewed here. ${ }^{53}$

However, one main advantage of the hedonic regression approach to constructing constant-quality price indexes for housing is that it can, in principle, tease out the separate contributions of the structure and of the land under the structure to the composite rental price or purchase price for the property. We will now explain how this can be done for purchase price indexes, but the rental price case is similar. ${ }^{54}$

If we momentarily think like a property developer who is planning to build a structure on a particular property, the total cost of the property after the structure is completed will be equal to the floor space area of the structure, say $A$ square feet, multiplied by the building cost per square foot, say $\alpha$, plus the cost of the land, which will be equal to the cost per square foot, say $\beta$, multiplied by the area of the land site, $B$. Now think of a sample of properties of the same general type, which have prices $p_{n}^{0}$ in period 0 and structure areas $A_{n}^{0}$ and land areas $B_{n}^{0}$ for $n=1, \ldots, N(0)$, and these prices

the hedonic regression technique for making quality adjustments, see Triplett (2004). For some recent examples of hedonic regressions for housing, see Gouriéroux and Laferrère (2006) and Li, Prud'homme, and Yu (2006).

51. An alternative approach to the hedonic method is to estimate separate hedonic regressions for both of the periods compared (i.e., for the base and current period). Predicted prices can then be generated in each period using the estimated hedonic regressions based on a constant characteristics set-say, the characteristics of the base period. A ratio of the geometric means of the estimated prices in each period would yield a pure price comparison based on a constant base-period set of characteristics. A hedonic index based on a constant current-period characteristic could also be compiled, as could such indexes based on a symmetric use of baseand current-period information. Heravi and Silver (2007) outline alternative formulations, and Silver and Heravi (2007) provide a formal analysis of the difference between this approach and that of the time dummy method for the case of one characteristic. Diewert, Heravi, and Silver (see chapter 4 of this volume) provide a generalization to an arbitrary number of characteristics.

52. This property of the hedonic regression method also applies to the stratification method. The main difference between the two methods is that continuous variables can appear in hedonic regressions (like the area of the structure and the area of the lot size), whereas the stratification method can only work with discrete ranges for the independent variables in the regression.

53. Basically, this recent literature makes connections between weighted hedonic regressions and traditional index number formulae that use weights; see Diewert (2003b, 2005b, 2006), de Haan (2003, 2004), and Silver and Heravi (2003, 2007). It is worth noting that a perceived advantage of the stratification method is that median price changes can be measured, as opposed to arithmetic mean ones that are implicit in, say, an ordinary least squares estimator. However, regression estimates can also be derived from robust estimators from which the parameter estimates for the price change will be similar to a median.

54. The following exposition is based on Diewert (2009). 
are equal to costs of the type just described, multiplied by error terms $\eta_{n}{ }^{0}$, which we assume have mean 1 . This leads to the following hedonic regression model for period 0 , where $\alpha$ and $\beta$ are the parameters to be estimated in the regression: ${ }^{55}$

$$
\begin{aligned}
p_{n}^{0} & =\left[\alpha A_{n}^{0}+\beta B_{n}^{0}\right] \eta_{n}^{0}, \\
n & =1, \ldots, N(0) .
\end{aligned}
$$

Taking logarithms of both sides of equation (32) leads to the following traditional additive errors regression model: ${ }^{56}$

$$
\begin{aligned}
\ln p_{n}{ }^{0} & =\ln \left[\alpha A_{n}^{0}+\beta B_{n}^{0}\right]+\varepsilon_{n}^{0}, \\
n & =1, \ldots, N(0),
\end{aligned}
$$

where the new error terms are defined as $\varepsilon_{n}^{0} \equiv \ln \eta_{n}^{0}$ for $n=1, \ldots, N(0)$ and are assumed to have 0 means and constant variances.

Now, consider the situation in a subsequent period $t$. The price per square meter of this type of structure will have changed from $\alpha$ to $\alpha \gamma^{t}$, and the land cost per square meter will have changed from $\beta$ to $\beta \delta^{t}$, where we interpret $\gamma^{t}$ as the period 0 to period t price index for the type of structure and $\delta^{t}$ as the period 0 to period t price index for the land that is associated with this type of structure. The period $t$ counterparts to equations (32) and (33) are:

$$
\begin{aligned}
p_{n}^{t} & =\left[\alpha \gamma^{t} A_{n}^{t}+\beta \delta^{t} B_{n}^{t}\right] \eta_{n}^{t} ; \\
n & =1, \ldots, N(t) ; \\
\ln p_{n}^{t} & =\ln \left[\alpha \gamma^{t} A_{n}^{t}+\beta \delta^{t} B_{n}^{t}\right]+\varepsilon_{n}^{t} \\
n & =1, \ldots, N(t),
\end{aligned}
$$

where $\varepsilon_{n}^{t} \equiv \ln \eta_{n}^{t}$ for $n=1, \ldots, N(t)$, the period $t$ property prices are $p_{n}^{t}$, and the corresponding structure and land areas are $A_{n}^{t}$ and $B_{n}^{t}$ for $n=1, \ldots$, $N(t)$.

Equations (33) and (35) can be run as a system of nonlinear hedonic regressions, and estimates can be obtained for the four parameters, $\alpha, \beta, \gamma^{t}$, and $\delta^{t}$. The main parameters of interest are of course $\gamma^{t}$ and $\delta^{t}$, which can be interpreted as price indexes for the price of a square meter of this type of structure and for the price per meter squared of the underlying land, respectively.

This very basic nonlinear hedonic regression framework can be generalized to encompass the traditional array of characteristics that are used in

55. Multiplicative errors with constant variances are more plausible than additive errors with constant variances; that is, it is more likely that expensive properties have relatively large absolute errors compared to very inexpensive properties. The multiplicative specification for the errors will be consistent with this phenomenon.

56. However, note that this model is not linear in the unknown parameters to be estimated. 
real estate hedonic regressions. Thus, suppose that we can associate with each property $n$ that is transacted in each period $t$ a list of $K$ characteristics $X_{n 1}^{t}, X_{n 2}^{t}, \ldots, X_{n K}^{t}$ that are price-determining characteristics for the structure and a similar list of $M$ characteristics $Y_{n 1}^{t}, Y_{n 2}^{t}, \ldots, Y_{n M}^{t}$ that are price-determining characteristics for the type of land that sits underneath the structure. The equations that generalize equations (33) and (35) to the present setup are the following ones:

$$
\begin{aligned}
\ln p_{n}^{0} & =\ln \left\{\left[\alpha_{0}+\sum_{k=1}^{K} X_{n k}^{0} \alpha_{k}\right] A_{n}^{0}+\left[\beta_{0}+\sum_{m=1}^{M} Y_{n m}^{0} \beta_{m}\right] B_{n}^{0}\right\}+\varepsilon_{n}^{0} ; \\
n & =1, \ldots, N(0) ; \\
\ln p_{n}^{t} & =\ln \left\{\gamma^{t}\left[\alpha_{0}+\sum_{k=1}^{K} X_{n k}^{t} \alpha_{k}\right] A_{n}^{t}+\delta^{t}\left[\beta_{0}+\sum_{m=1}^{M} Y_{n m}^{t} \beta_{m}\right] B_{n}^{t}\right\}+\varepsilon_{n}^{t} ; \\
n & =1, \ldots, N(t),
\end{aligned}
$$

where the parameters to be estimated are now the $K+1$ quality of structure parameters, $\alpha_{0}, \alpha_{1}, \ldots, \alpha_{K}$, the $M+1$ quality of land parameters, $\beta_{0}, \beta_{1}$, $\ldots, \beta_{M}$, the period $t$ price index for structures parameter $\gamma^{t}$, and the period $t$ price index for the land underlying the structures parameter $\delta^{t}$. Note that $\left[\alpha_{0}+\sum_{k=1}^{K} X_{n k}^{0} \alpha_{k}\right]$ in equations (36) and (37) replaces the single structures quality parameter $\alpha$ in equations (33) and (35), and $\left[\beta_{0}+\sum_{m=1}^{M} Y_{n m}^{0} \beta_{m}\right]$ in equations (35) and (37) replaces the single land quality parameter $\beta$ in equations (31) and (33).

In order to illustrate how $X$ and $Y$ variables can be formed, we consider the list of exogenous variables in the hedonic housing regression model reported by $\mathrm{Li}$, Prud'homme, and $\mathrm{Yu}(2006,23)$. The following variables in their list of exogenous variables can be regarded as variables that affect structure quality; that is, they are $X$-type variables: number of reported bedrooms, number of reported bathrooms, number of garages, number of fireplaces, age of the unit, age squared of the unit, exterior finish is brick or not, dummy variable for new units, unit has hardwood floors or not, heating fuel is natural gas or not, unit has a patio or not, unit has a central built-in vacuum-cleaning system or not, unit has an indoor or outdoor swimming pool or not, unit has a hot tub unit or not, unit has a sauna or not, and unit has air-conditioning or not. The following variables can be regarded as variables that affect the quality of the land; that is, they are $Y$-type location variables: unit is at the intersection of two streets or not (corner lot or not), unit is at a cul-de-sac or not, shopping center is nearby or not, and various suburb location dummy variables..$^{57}$

57. Of course, in practice, some of the land or location variables could act as proxies for unobserved structure quality variables. There are also some interesting conceptual problems associated with the treatment of rental apartments and owner-occupied apartments or condominiums. Obviously, separate hedonic regressions would be appropriate for apartments, because their structural characteristics are quite different from detached housing. For rental apartments, the sale price of the apartment can be the dependent variable, and there will be associated amounts of structure area and land area. For a condo sale, the price of the single 
The nonlinear hedonic regression model defined by equations (36) and (37) is very flexible and can accomplish what none of the other approaches to obtaining constant-quality purchase price indexes for housing were able to accomplish: namely, a decomposition of a property price index into structures and land components. However, this model has a cost compared to the usual hedonic regression model that appears in the housing literature: these models are generally linear in the unknown parameters to be estimated, whereas the model defined by equations (36) and (37) is nonlinear. It remains to be seen whether such a nonlinear model can be estimated successfully for a large data set. ${ }^{58}$

It is useful to discuss the merits of the hedonic regression method compared to other methods for purchase price indexes for housing.

The main advantages of the hedonic regression method are as follows:

- Property price indexes can be constructed for different types and locations of the property class under consideration.

- The method is probably the most efficient method for making use of the available data; that is, the method uses all of the information on housing sales in each sample period in a nontrivial way, whereas the repeat sales model does not use any information at all on isolated sales that take place in only one of the sample periods.

- The method can be modified to give a decomposition of property prices into land and structures components; none of the other methods previously described can do this.

- If the list of property characteristics is sufficiently detailed so that, for example, it can be determined whether major maintenance projects have been undertaken and when they were done (such as a new roof), then it is possible to deal adequately with the depreciation and renovations problem, and a byproduct of the hedonic regression method would be fairly accurate depreciation rates for housing structures.

If the age of the structure was a characteristic in the hedonic regression and if there were no renovations made to the structure since its birth, then it would be straightforward to use the results of the hedonic regression in order to obtain scientific- or evidence-based estimates of structure depreciation rates by type of housing. However, as noted earlier, the econometrician will not have information on additions and renovations on each property at his or her disposal. Thus, hedonic regressions that have age as a character-

unit is the dependent variable, while the dependent variables in the bare-bones model would be the structure area of the apartment, plus the apartment's share of commonly owned facilities, plus the apartment's share of the lot area. In the end, we want to be able to impute the value of the property into land and structure components, so the hedonic regression should be set up to accomplish this task.

58. Of course, large data sets can be transformed into smaller data sets if we run separate hedonic regressions for various property strata! 
istic frequently find that the value of the property increases once a certain age is reached. This phenomenon is likely due to the effects of renovations and remodeling, ${ }^{59}$ and because these renovation expenditures are generally unknown and hence cannot be entered as an explanatory variable for the hedonic regression, hedonic regression estimates of depreciation may be severely biased downward. A related problem is due to the fact that some homeowners will not undertake normal maintenance expenditures ${ }^{60}$ on their property, and as a result, depreciation will be abnormal on their properties. We term these effects the depreciation and renovations problem that causes problems for all approaches to the construction of constant-quality housing price indexes. However, the most promising method for overcoming these problems is the hedonic regression approach with renovation and maintenance expenditures as explanatory variables. We will pursue this approach a bit further in section 12.8.4.

The main disadvantages of the hedonic method are as follows:

- The method is data intensive (i.e., it requires information on property characteristics), and thus it is relatively expensive to implement.

- The method is not entirely reproducible; that is, different statisticians will enter different property characteristics into the regression, ${ }^{61}$ will assume different functional forms for the regression equation, ${ }^{62}$ will make different stochastic specifications, and perhaps will choose different transformations of the dependent variable ${ }^{63}$ all of which may lead to different estimates of the amount of overall price change.

- The method is not easy to explain to users.

Our conclusion at this point is that there is no completely satisfactory solution to the problems involved in constructing constant-quality price indexes for the stock of owner-occupied housing. The hedonic regression approach seems to be superior in principle to the repeat sales approach, because the latter approach cannot deal adequately with depreciation and renovations to the structure of a housing unit. However, in practice, the hedonic regression approach has limitations due to its lack of reproduc-

59. If a very old dwelling unit is not renovated, then it will be demolished. Thus, very longlived housing structures will generally have extensive renovations made to them.

60. "In following this sequence, it may appear as though there are many separate and distinct entities called 'capital.' However, a comparison of each case reveals the following unity: all aspects of capital ultimately are derived from the decision to defer current consumption in order to enhance or maintain expected future consumption" (Hulten 2006, 195). Following Hulten, it would be conceptually correct to capitalize all home maintenance expenditures. However, national income accountants capitalize only above-normal maintenance expenditures.

61. Note that the same criticism can be applied to stratification methods; that is, different analysts will come up with different stratifications.

62. Functional form problems for hedonic regressions are discussed in Diewert (2003a, 2003b).

63. For example, the dependent variable could be the sales price of the property, its logarithm, or the sales price divided by the area of the structure, and so on. 
ibility and the lack of information on repairs and renovations. But despite these limitations, the hedonic regression method is probably the best method that could be used in order to construct constant-quality price indexes for various types of property. ${ }^{64}$

Hedonic regression analysis can also be applied to the construction of constant-quality indexes of market rents for owner-occupied structures. Crone, Nakamura, and Voith (2000) have written a very useful paper using hedonic techniques to estimate both a rent index and a selling-price index for housing in the United States. They follow the BEA methodology for rental equivalence by suggesting that capitalization rates (i.e., the ratio of the market rent of a housing property to its selling price) can be applied to an index of housing selling prices in order to obtain an imputed rent index for $\mathrm{OOH}$. Note that equation (8) (after dividing both sides of the equation by the asset price of the house) provides a theoretical foundation for this methodological approach; the transformed equation shows that the capitalization rate is a function of the nominal interest rate, the depreciation rate, and the expected asset inflation over the period. If these factors are relatively constant over time, then the BEA methodological approach is justified.

There are many other difficulties associated with measuring the price and quantity of $\mathrm{OOH}$ services. The following section discusses some of the problems involved in modeling the costs of certain expenditures that are tied to the ownership of a home.

\subsection{The Treatment of Costs Tied to Owner-Occupied Housing}

There are many costs that are quite directly tied to home ownership. However, it is not always clear how these costs can be decomposed into price and quantity components. Several of these cost components are listed next, and some suggestions for forming their associated prices are suggested.

\subsubsection{The Treatment of Mortgage Interest Costs}

The derivation of the user cost or expected rental price that an owner of a home should charge for the use of the dwelling unit for one period implicitly assumed that the owner had no mortgage interest costs, so the interest rate $r^{0}$ referred to the owner's opportunity cost of equity capital. In this section, the case where the owner has a mortgage on the property is considered.

Recall the notation in section 12.6 where the user cost or imputed rental cost, $R^{0}$, for an equity-financed dwelling unit was obtained (see equation [20]). Suppose now that the property purchase is partly financed by a mortgage of $M^{0}$ dollars at the beginning of period 0 . Let $f^{0}$ be the fraction of

64. This evaluation agrees with that of Hoffmann and Lorenz: "As far as quality adjustment is concerned, the future will certainly belong to hedonic method" $(2006,15)$. 
the beginning-of-period 0 market value of the property that is financed by the mortgage, so that

$$
M^{0}=f^{0} V^{0}=f^{0}\left[P_{S}^{0} Q_{S}^{0}+P_{L}^{0} Q_{L}^{0}\right] .
$$

Let the one-period nominal mortgage interest rate be $r_{M}^{0}$. The owner's period 0 benefits of owning the dwelling unit remain the same as in section 12.6 and are equal to $V^{1 a}$, defined by equation (19). However, the period 0 costs are now made up of an explicit mortgage interest cost equal to $M^{0}\left(1+r_{M}^{0}\right)$, plus an imputed equity cost equal to $\left(1-f^{0}\right) V^{0}\left(1+r^{0}\right)$. Thus, the new imputed opportunity cost for using the property during period 0 is now

$$
\begin{aligned}
R^{0} \equiv & \left(1-f^{0}\right) V^{0}\left(1+r^{0}\right)+M^{0}\left(1+r_{M}^{0}\right)-V^{1 a} \\
= & \left(1-f^{0}\right)\left[P_{S}^{0} Q_{S}^{0}+P_{L}^{0} Q_{L}^{0}\right]\left(1+r^{0}\right)+f^{0}\left[P_{S}^{0} Q_{S}^{0}+P_{L}^{0} Q_{L}^{0}\right]\left(1+r_{M}^{0}\right) \\
& -\left[P_{S}^{1 a}\left(1-\delta_{0}\right) Q_{S}^{0}+P_{L}^{1 a} Q_{L}^{0}\right] \\
= & p_{S}^{0 *} Q_{S}^{0}+p_{L}^{0 *} Q_{L}^{0}
\end{aligned}
$$

where the new mortgage interest-adjusted period 0 user costs of structures and land, $p_{S}{ }^{0 *}$ and $p_{L}{ }^{0 *}$, are defined as follows:

$$
\begin{aligned}
p_{S}^{0 *} & \equiv\left[\left(1+r^{0}\right)\left(1-f^{0}\right)+\left(1+r_{M}^{0}\right) f^{0}-\left(1+i_{S}^{0}\right)\left(1-\delta_{0}\right)\right] P_{S}^{0} \\
& =\left[\left(r^{0}-i_{S}^{0}\right)\left(1-f^{0}\right)+\left(r_{M}^{0}-i_{S}^{0}\right) f^{0}+\delta_{0}\left(1+i_{S}^{0}\right)\right] P_{S}^{0} \\
p_{L}^{0 *} & \equiv\left[\left(1+r^{0}\right)\left(1-f^{0}\right)+\left(1+r_{M}^{0}\right) f^{0}-\left(1+i_{L}^{0}\right)\right] P_{S}^{0} \\
& =\left[\left(r^{0}-i_{L}^{0}\right)\left(1-f^{0}\right)+\left(r_{M}^{0}-i_{L}^{0}\right) f^{0}\right] P_{S}^{0} .
\end{aligned}
$$

Comparing the new user costs for structures and land defined by equations (40) and (41) to the corresponding equity-financed user costs defined by equations (21) and (22) in section 12.6 , it can be seen that the old equity opportunity cost of capital $r^{0}$ is now replaced by a weighted average of this equity opportunity cost and the mortgage interest rate, $r^{0}\left(1-f^{0}\right)+r_{M}^{0} f^{0}$, where $f^{0}$ is the fraction of the beginning-of-period 0 value of the dwelling unit that is financed by the mortgage.

Central bankers often object to the inclusion of mortgage interest in a consumer price index. However, examination of the last equation in equations (40) and in (41) shows that the nominal mortgage interest rate $r_{M}^{0}$ is offset by anticipated price inflation in the price of structures $-i_{S}^{0}$ in equation (40) - and in the price of land $-i_{L}^{0}$ in equation (41) — so as usual, what counts in these user cost formulae are real interest costs rather than nominal ones.

\subsubsection{The Treatment of Property Taxes}

Recall the user costs of structures and land defined by equations (21) and (22) in section 12.6. It is now supposed that the owner of the housing unit must pay the property taxes $T_{S}^{0}$ and $T_{L}^{0}$ for the use of the structure and land, 
respectively, during period $0 .{ }^{65}$ We define the period 0 structures tax rate $\tau_{S}^{0}$ and land tax rate $\tau_{L}^{0}$ as follows:

$$
\begin{aligned}
& \tau_{S}^{0} \equiv \frac{T_{S}^{0}}{P_{S}^{0} Q_{S}^{0}} ; \\
& \tau_{L}^{0} \equiv \frac{T_{L}^{0}}{P_{L}^{0} Q_{L}^{0}} .
\end{aligned}
$$

The new imputed rent for using the property during period $0, R^{0}$, including the property tax costs, is defined as follows:

$$
\begin{aligned}
R^{0} \equiv & V^{0}\left(1+r^{0}\right)+T_{S}^{0}+T_{L}^{0}-V^{1 a} \\
= & {\left[P_{S}^{0} Q_{S}^{0}+P_{L}^{0} Q_{L}^{0}\right]\left(1+r^{0}\right)+\tau_{S}^{0} P_{S}^{0} Q_{S}^{0}+\tau_{L}^{0} P_{L}^{0} Q_{L}^{0} } \\
& -\left[P_{S}^{0}\left(1+i_{S}^{0}\right)\left(1-\delta_{0}\right) Q_{S}^{0}+P_{L}^{0}\left(1+i_{L}^{0}\right) Q_{L}^{0}\right] \\
= & p_{S}^{0} Q_{S}^{0}+p_{L}^{0} Q_{L}^{0},
\end{aligned}
$$

where separate period 0 tax-adjusted user costs of structures and land, $p_{S}{ }^{0}$ and $p_{L}{ }^{0}$, are defined as follows:

$$
\begin{aligned}
p_{S}^{0} & \equiv\left[\left(1+r^{0}\right)-\left(1+i_{S}^{0}\right)\left(1-\delta_{0}\right)+\tau_{S}^{0}\right] P_{S}^{0} \\
& =\left[r^{0}-i_{S}^{0}+\delta_{0}\left(1+i_{S}^{0}\right)+\tau_{S}^{0}\right] P_{S}^{0} ; \\
p_{L}^{0} & \equiv\left[\left(1+r^{0}\right)-\left(1+i_{L}^{0}\right)+\tau_{L}^{0}\right] P_{L}^{0} \\
& =\left[r^{0}-i_{L}^{0}+\tau_{S}^{0}\right] P_{L}^{0} .
\end{aligned}
$$

Thus, the property tax rates, $\tau_{S}{ }^{0}$ and $\tau_{L}{ }^{0}$ (defined by equations [42] and [43]), enter the user costs of structures and land, $p_{S}{ }^{0}$ and $p_{L}{ }^{0}$ (defined by equations [45] and [46]), in a simple additive manner; that is, these terms are additive to the previous depreciation and real interest rate terms.

\subsubsection{The Treatment of Property Insurance}

At first glance, it would seem that property insurance could be treated in the same manner as the treatment of property taxes in the previous subsection. Thus, let $C_{S}{ }^{0}$ be the cost of insuring the structure at the beginning of period 0 , and define the period 0 structures premium rate $\gamma_{S}{ }^{0}$ as follows:

$$
\gamma_{S}^{0} \equiv \frac{C_{S}^{0}}{P_{S}^{0} Q_{S}^{0}} .
$$

The new imputed rent for using the property during period $0, R^{0}$, including property tax and insurance costs, is defined as follows:

65. If there is no breakdown of the property taxes into structures and land components, then just impute the overall tax into structures and land components based on the beginningof-period values of both components. 


$$
\begin{aligned}
R^{0} \equiv & V^{0}\left(1+r^{0}\right)+T_{S}^{0}+T_{L}^{0}+C_{S}^{0}-V^{1 a} \\
= & {\left[P_{S}^{0} Q_{S}^{0}+P_{L}^{0} Q_{L}^{0}\right]\left(1+r^{0}\right)+\tau_{S}^{0} P_{S}^{0} Q_{S}^{0}+\tau_{L}^{0} P_{L}^{0} Q_{L}^{0}+\gamma_{S}^{0} P_{S}^{0} Q_{S}^{0} } \\
& -\left[P_{S}^{0}\left(1+i_{S}^{0}\right)\left(1-\delta_{0}\right) Q_{S}^{0}+P_{L}^{0}\left(1+i_{L}^{0}\right) Q_{L}^{0}\right] \\
= & p_{S}^{0} Q_{S}^{0}+p_{L}^{0} Q_{L}^{0},
\end{aligned}
$$

where separate period 0 tax-and insurance-adjusted user costs of structures and land, $p_{S}^{0}$ and $p_{L}^{0}$, are defined as follows:

$$
\begin{aligned}
p_{S}^{0} & \equiv\left[\left(1+r^{0}\right)-\left(1+i_{S}^{0}\right)\left(1-\delta_{0}\right)+\tau_{S}^{0}+\gamma_{S}^{0}\right] P_{S}^{0} \\
& =\left[r^{0}-i_{S}^{0}+\delta_{0}\left(1+i_{S}^{0}\right)+\tau_{S}^{0}+\gamma_{S}^{0}\right] P_{S}^{0} ; \\
p_{L}^{0} & \equiv\left[\left(1+r^{0}\right)-\left(1+i_{L}^{0}\right)+\tau_{L}^{0}\right] P_{L}^{0} \\
& =\left[r^{0}-i_{L}^{0}+\tau_{S}^{0}\right] P_{L}^{0} .
\end{aligned}
$$

Thus, the insurance premium rate $\gamma_{S}^{0}$ appears in the user cost of structures, $p_{S}^{0}$ (defined by equation [49]), in an additive manner, analogous to the additive property tax rate term. ${ }^{66}$ If it is desired to have a separate CPI price component for insurance, then the corresponding period 0 and period 1 prices can be defined as $\gamma_{S}^{0} P_{S}^{0}$ and $\gamma_{S}^{1} P_{S}^{1}$, respectively, while the corresponding period 0 and period 1 expenditures can be defined as $\gamma_{S}^{0} P_{S}^{0} Q_{S}^{0}$ and $\gamma_{S}^{1} P_{S}^{1}(1$ $-\delta) Q_{S}^{0}$, respectively. ${ }^{67}$ Of course, if this separate treatment is implemented, then these terms have to be dropped from the corresponding user costs of structures.

This treatment of property taxation and insurance assumes that the property taxes and the premium payments are made at the end of the period under consideration. While this may be an acceptable approximation for the payment of property taxes, it is not acceptable for the payment of insurance premiums: the premium must be paid at the beginning of the period of protection rather than at the end. When this complication is taken into account, the user cost of structures becomes

$$
\begin{aligned}
p_{S}^{0} & \equiv\left[\left(1+r^{0}\right)-\left(1+i_{S}^{0}\right)\left(1-\delta_{0}\right)+\tau_{S}^{0}+\gamma_{S}^{0}\left(1+r^{0}\right)\right] P_{S}^{0} \\
& =\left[r^{0}-i_{S}^{0}+\delta_{0}\left(1+i_{S}^{0}\right)+\tau_{S}^{0}+\gamma_{S}^{0}\left(1+r^{0}\right)\right] P_{S}^{0} .
\end{aligned}
$$

There are some additional problems associated with the modeling of property insurance:

- The preceding user cost derivations assume that the risk of property damage remains constant from period to period. If the risk of damage changes, then an argument can be made for quality adjustment of the

66. This treatment of property insurance dates back to Walras $(1954,268-9)$.

67. Similarly, if it is desired to have a separate CPI price component for property taxes on structures, then the corresponding period 0 and period 1 prices can be defined as $\tau_{S}^{0} P_{S}^{0}$ and $\tau_{S}^{1} P_{S}^{1}$, respectively, while the corresponding period 0 and period 1 expenditures can be defined as $\tau_{S}^{0} P_{S}^{0} Q_{S}^{0}$ and $\tau_{S}^{1} P_{S}^{1}(1-\delta) Q_{S}^{0}$, respectively. 
premium to hold constant the risk so that like can be compared with like.

- The gross premium approach to insurance is taken in the previous treatment; that is, it is assumed that dwelling owners pay premiums for property protection services, regardless of whether they have a claim. In the net premium approach, payments to settle claims are subtracted from the gross premium payments.

- The property protection may not be complete; that is, the insurance policy may have various limitations on the type of claim that is allowed, and there may be a deductible or damage threshold, below which no claim is allowed. If the deductible changes from period to period, then the price statistician is faced with a rather complex quality-adjustment problem.

Thus, it can be seen that there are some difficult problems that remain to be resolved in this area.

\subsubsection{The Treatment of Maintenance and Renovation Expenditures}

Another problem associated with home ownership is the treatment of maintenance expenditures, major repair expenditures, and expenditures associated with renovations or additions.

Empirical evidence suggests that the normal decline in a structure due to the effects of aging and use can be offset by maintenance and renovation expenditures. How exactly should these expenditures be treated in the context of modeling the costs and benefits of home ownership?

A common approach in the national accounts literature is to treat major renovation and repair expenditures as capital formation and to treat smaller routine maintenance and repair expenditures as current expenditures. If this approach is followed in the CPI context, then these smaller routine maintenance expenditures can be treated in the same manner as other nondurable goods and services. The major renovation and repair expenditures do not enter the CPI in the period that they are made; instead, these expenditures are capitalized and added to expenditures on new structures for the period under consideration, so period 0 investment in structures in constant dollars, say $I_{S}^{0}{ }^{68}$ would include both types of expenditures. Let $Q_{S}^{0}$ and $Q_{S}^{1}$ be the stocks (in constant-quality units) of owner-occupied structures in the reference population at the beginning of period 0 and period 1 , respectively. Then, if the geometric model of depreciation is used so that the constant period-to-period depreciation rate $\delta$ is applicable, then the beginning-ofperiod 1 stock of owner-occupied structures $Q_{S}^{1}$ is related to the beginning-

68. Let $V I_{S}^{0}$ be the nominal value of investment in new owner-occupied structures in period 0 , plus the value of major renovation expenditures made during period 0 . Then, the constantdollar quantity of investment could be defined as $I_{S}^{0} \equiv V I_{S}^{0} / P_{S}^{0}$, where $P_{S}^{0}$ is the period 0 construction price index for new structures. 
of-period 0 stock of structures $Q_{S}^{0}$ and to the period 0 investment in structures $I_{S}^{0}$, according to the following equation:

$$
Q_{S}^{1}=(1-\delta) Q_{S}^{0}+I_{S}^{0} .
$$

Thus, if declining-balance depreciation is assumed for structures, then the treatment of major repair and renovation expenditures does not pose major conceptual problems using a conventional capital accumulation model: it is only necessary to have an estimate for the monthly or quarterly depreciation rate $\delta$, a starting value for the stock of owner-occupied structures for some period, information on new purchases of residential housing structures by the household sector, information on expenditures by owners on major repairs and renovations, and a construction price index for new residential structures. With this information on a timely basis, up-to-date CPI weights for the stock of owner-occupied structures could be constructed. ${ }^{69}$

What would a hedonic regression model look like, taking into account the approximate additivity of the value of the housing structure and the value of the land that the structure sits on? If the renovations problem is ignored and geometric depreciation of the structure is assumed, then the value of a housing unit $n$ in period $t$ that is $m$ periods old, $V_{n}^{t}$, should be equal to the depreciated value of the structure, plus the value of the land, plus an error term; that is, the following relationship should hold approximately, assuming geometric depreciation of the structure: ${ }^{70}$

$$
\begin{gathered}
V_{n}^{t}=P_{S}^{t}(1-\delta)^{m} Q_{S n}+P_{L}^{t} Q_{L} ; \\
n=1, \ldots, N,
\end{gathered}
$$

where $\delta$ is the one-period geometric depreciation rate, $Q_{S n}$ is the number of square meters of floor space of the original structure for housing unit $n$, and $Q_{L}$ is the number of square meters of land that the housing structure sits on. The variable $P_{S}{ }_{S}$ is the beginning-of-period t price level for structures of this type, and $P_{L}{ }^{t}$ is the corresponding price of land for this class of housing units. As long as there is more than one vintage of structure in the sample (i.e., observations corresponding to different ages $m$ of the structure), then the parameters $P_{S}^{t}, P_{L}^{t}$, and $\delta$ can be identified by running a nonlinear regression model using equation (53), or more appropriately, by taking logarithms of both sides of equation (53) and adding error terms. Why can the price levels be identified in the present hedonic regression model, whereas they could not be identified in section $12.5 ?^{71}$ The answer is that the hedonic model in equation (53) does not assume property-specific quality-adjustment factors

69. However, the practical problems involved in obtaining all of this information on a timely basis are not trivial. Variants of this approach were used by Christensen and Jorgenson (1969) and Leigh (1980) in order to construct estimates of the stock of residential structures in the United States.

70. We have omitted the multiplicative error term in equation (53).

71. Recall the discussion around equation (15) in section 12.5 . 
for each housing unit; instead, all of the housing units in the class of properties in the sample are assumed to be of comparable quality once prices are adjusted for the age of the unit and the quantity (in square meters) of original structure and the quantity of land.

Unfortunately, many housing structures that may have started their lives as identical structures do not remain the same over time, due to differing standards of maintenance, as well as major renovations and additions to some of the structures. To model this phenomenon, let $R_{n}{ }^{t}$ be real maintenance, repair, and renovation expenditures on housing unit $n$ during period $t$, and suppose that these real expenditures depreciate at the geometric rate $\delta_{R}$. It is reasonable to assume that these expenditures $a d d$ to the value of the housing unit, so equation (53) should be replaced by the following equation:

$$
\begin{gathered}
V_{n}^{t}=P_{S}^{t}(1-\delta)^{m} Q_{S n}+P_{R}^{t}\left[R_{n}^{t}+\left(1-\delta_{R}\right) R_{n}^{t-1}+\left(1-\delta_{R}\right)^{2} R_{n}^{t-2}+\ldots\right. \\
\left.+\left(1-\delta_{R}\right)^{v} R_{n}^{t-v}\right]+P_{L}^{t} Q_{L},
\end{gathered}
$$

where $P_{R}{ }^{t}$ is the period $t$ price level for real maintenance, repair, and renovation expenditures on this class of housing units. If information on these real renovation and repair expenditures, $R_{n}^{t}, R_{n}^{t-1}, R_{n}^{t-2}, \ldots, R_{n}^{t-v}$, is available for each housing unit in the sample of housing units that sold in period $t$, then the parameters $P_{S}^{t}, P_{L}^{t}, P_{R}^{t}, \delta$, and $\delta_{R}$ can be identified by taking logarithms of both sides of equation (54) and running a nonlinear regression model. ${ }^{72}$

However, a major practical problem with implementing a hedonic regression model along these lines is that usually, accurate data on renovation and repair expenditures on a particular dwelling unit between the construction of the initial housing unit and the present period are not available. Without accurate data on repairs and renovations, it will be impossible to obtain accurate estimates of the unknown parameters in the hedonic regression model.

A final practical problem with this hedonic regression model will be mentioned. Theoretically, following Hulten (2006, 195), normal maintenance expenditures could be included in the renovation expenditure terms $R_{n}^{t}$ in equation (54). If this is done, then including normal maintenance expenditures in $R_{n}^{t}$ will have the effect of increasing the estimated depreciation rates $\delta$ and $\delta_{R}$. Thus, different statistical agencies that have different criteria for deciding where to draw the line between normal maintenance and major repair and renovations will produce different estimated depreciation rates.

It can be seen that here, as was the case for property insurance, there are many unresolved issues in this area: a statistical agency best practice has not yet emerged.

72. Alternatively, if price levels are available for $P_{S}^{t}$ and $P_{R}^{t}$ from construction price indexes, then these parameters do not have to be estimated. 


\subsubsection{The Treatment of the Transactions Costs of Home Purchase}

Another cost of home ownership needs to be discussed. Normally, when a family purchases a dwelling unit, they have to pay certain fees and costs, which can include:

- The commissions of real estate agents who help the family find the right property

- Various transactions taxes that governments can impose on the sale of the property

- Various legal fees that might be associated with the transfer of title for the property

Should these fees be immediately expensed in the period of purchase, or should they simply be regarded as part of the purchase price of the property and hence be depreciated over time in a manner analogous to the treatment of structures in the national accounts? ?3 $^{73}$

An argument can be made for either treatment. From the viewpoint of the opportunity cost treatment of purchases of durable goods, the relevant price of the dwelling unit in the periods following the purchase of the property is the after-tax and transactions fees value of the property. This viewpoint suggests that the transactions costs of the purchaser should be immediately expensed in the period of purchase. However, from the viewpoint of a landlord who has just purchased a dwelling unit for rental purposes, it would not be sensible to charge the tenant the full cost of these transactions fees in the first month of rent. The landlord would tend to capitalize these costs and recover them gradually over the time period that the landlord expects to own the property. Thus, either treatment could be justified, and the statistical agency will have to decide which treatment is most convenient from their particular perspective.

\subsection{User Costs for Landlords versus Owners}

In the previous section, the various financial costs associated with home ownership were discussed. Both homeowners and landlords face these costs. Thus, they will be reflected in market rents, and this fact must be kept in mind if the imputed rent approach is used to value the services of OOH. If some or all of these associated costs of $\mathrm{OOH}$ are covered elsewhere in the CPI (e.g., home insurance could be separately covered), then the value of imputed rents for $\mathrm{OOH}$ must be reduced by the amount of these expenditures covered elsewhere.

73. The Australian Bureau of Statistics follows the second alternative and depreciates the transactions costs of purchasing a dwelling unit over the average length of time a property of that type is held. 
However, in addition to the financial costs of home ownership that were covered in the previous section, landlords face a number of additional costs compared to the homeowner. These additional costs will be reflected in market rents, and thus if market rents are used to impute the services provided by the ownership of a dwelling unit, then these extra costs should also be removed from the market rents that are used for imputation purposes, because they will not be relevant for owner occupiers. These additional landlordspecific costs will be discussed in sections 12.9.1 to 12.9.5. We note that these additional costs will be reflected in market rental rates, and thus they belong in a CPI that is applicable for renters. However, if market rental rates are used as an imputed opportunity cost for the use of an owner-occupied dwelling unit, then we are suggesting that the unadjusted market rental rate is not a true opportunity cost; that is, the extra costs to be discussed in sections 12.9.1 to 12.9.5 should be removed to the extent possible in order to reflect a true opportunity cost of consuming the services of an owned home over the reference period. Thus, adjusted market rents should be used in place of actual market rents for imputation purposes.

\subsubsection{Damage Costs}

Tenants do not have the same incentive to take care of a rental property compared to an owned property, so depreciation costs for a rental property are likely to exceed depreciation rates for comparable owned properties. If these expected damage costs are included in the rent, then they should be subtracted from the rent when forming imputed rent for an owner-occupied dwelling unit. If the expected damage costs are approximately equal to an up-front damage deposit, then the market rent does not have to be adjusted when forming market equivalent rent for an owner-occupied dwelling unit.

\subsubsection{Nonpayment of Rent and Vacancy Costs}

At times, tenants run into financial difficulties and are unable to pay landlords the rent that is owed. Usually, eviction is a long, drawn-out process, so landlords can lose several months of rent before a nonpaying tenant finally leaves. The landlord also incurs extra costs compared to a homeowner when a rental property remains vacant due to lack of demand. ${ }^{74}$ These extra costs will be reflected in market rents but should not be reflected in the user costs of $\mathrm{OOH}$.

\subsubsection{Billing and Maintenance Costs}

A (large) landlord may have to rent office space and employ staff to send out monthly bills to tenants and to respond to requests for maintenance. A

74. The demand for rental properties can vary substantially over the business cycle, and this can lead to depressed rents or very high rents compared to the user costs of home ownership. Thus, imputed rents based on market rents of similar properties can differ substantially from the corresponding user costs of $\mathrm{OOH}$ over the business cycle. 
homeowner who provides his or her time in order to provide maintenance services ${ }^{75}$ provides this time at his or her after-income tax wage rate, which may be lower than the before-income tax wage rate that a landlord must pay his or her employees. The net effect of these factors leads to higher market rents compared to the corresponding owner-occupied user cost.

\subsubsection{The Opportunity Cost of Capital}

The homeowner's after-tax opportunity cost of capital that appeared in the various user cost formulae considered earlier in this chapter will typically be lower than the landlord's before-tax opportunity cost of capital. ${ }^{76}$ Put another way, the landlord has an extra income tax cost compared to the homeowner. In addition, the landlord may face a higher risk premium for the use of capital due to the risks of damage and nonpayment of rent. However, care must be taken so that these additional landlord costs are not counted twice (i.e., in the present subsection, as well as in subsections 12.9.1 and 12.9.2).

\subsubsection{The Supply of Additional Services for Rental Properties}

Often, rental properties will contain some major consumer durables that homeowners have to provide themselves, such as refrigerators, stoves, washing machines, dryers, and air-conditioning units. In addition, landlords may pay for electricity or fuel in some rental apartments. Thus, to make the market rental comparable to an owner-occupied imputed rent, the market rental should be adjusted downward to account for these factors (which will appear elsewhere in the expenditures of owner occupiers).

\subsubsection{Which Approach Will Give the Highest Expenditure Weight?}

The factors just listed will tend to make observed market rental prices higher than the corresponding user cost for an owner occupier of a property of the same quality. Thus, if the imputed rental approach is used to value the services of $\mathrm{OOH}$, then these market-based rents should be adjusted downward to account for those factors.

Although all of the factors will tend to lead to an upward bias if unadjusted market rental rates are used to impute the services of $\mathrm{OOH}$, there is another factor not discussed thus far that could lead to a large downward bias. That factor is rent controls.

The previous discussion suggests that under normal conditions, where rent controls are not a factor, the acquisitions approach to the treatment of

75. Typically, these imputed maintenance costs will not appear in the CPI, but if the user cost of an owned dwelling unit is to be comparable with the market rent of a similar property, these imputed labor costs should be included.

76. Due to the complexity of the topic, we have not modeled the implications of the treatment of housing in the system of personal and business income taxation that is relevant for a particular housing unit. 
$\mathrm{OOH}$ will give rise to the smallest expenditures, the user cost approach will give rise to the next-highest level of expenditures, and the use of imputed market rentals will give the largest level of expenditures for owner-occupied housing. However, these conclusions depend on the assumption that market rents for expensive dwelling units are formed using the same user cost considerations that are used in forming market rents for inexpensive dwelling units, and this assumption does not appear to be satisfied. The problem is this: Garner and Short (2001) and Heston and Nakamura (2009) present substantial evidence that rent-to-value ratios decline as the value of the dwelling unit increases. ${ }^{77}$ This cross-sectional decline is simply too large to be reconciled with rents for all types of housing based on user cost considerations. Thus, if we take equation (9) as an approximate guide to the formation of the market rent of a housing asset relative to its starting stock value, the rent-to-value ratio should be equal to $r^{0}-i^{0}+\delta$, where $r^{0}$ is defined as the nominal interest rate or opportunity cost of financial capital, $i^{0}$ is the anticipated asset inflation rate, and $\delta$ is the depreciation rate. There is no reason for the opportunity cost of capital or for the expected asset inflation rate to change substantially as we move from cheaper to more expensive dwelling units. If the land component of more expensive housing becomes larger, then we could expect a drop in the combined depreciation rate for the structure and land components as we move toward more expensive properties, but because structure depreciation rates are quite small, a drop in a small number cannot explain the huge drop in the rent-to-asset value ratio as the dwelling unit asset value increases. Thus, it seems that the user cost approach to pricing the services of owner-occupied housing will probably give a higher expenditure share to $\mathrm{OOH}$ than the rental equivalence approach will give, even over long periods of time. ${ }^{78}$

The preceding discussion suggests that while the acquisitions approach to the treatment of $\mathrm{OOH}$ will give rise to the smallest expenditures, it is not certain whether the user cost or rental equivalence approach will give rise to the next-highest level of expenditures.

77. Heston and Nakamura $(2009,121)$ summarize the BEA evidence as follows: "The rent to value ratios reported are about 17 percent for dwellings under $\$ 20,000$ and 6 percent for dwellings in the $\$ 200,000-300,000$ class in the early 1990s." Heston and Nakamura $(2009,121)$ present their own evidence for U.S. and Caribbean locations that the ratio of rent to the value of a house falls dramatically as the house value increases; they find that the rent-to-value ratio for expensive houses is about one-half the corresponding ratio for inexpensive houses.

78. It is well known that capitalization rates (the ratio of rent to asset value) for housing vary substantially over time due to changes in nominal interest rates, depreciation rates, and expected housing inflation rates; for example, see Crone, Nakamura, and Voith (2000), Verbrugge (2006), Girouard et al. (2006), Garner and Verbrugge (2009), and Heston and Nakamura (2009). However, this time-series variation in capitalization rates could perhaps be explained by variations in nominal interest rates and variations in expected housing inflation rates (although Verbrugge [2006] and Garner and Verbrugge [2009] show that this is unlikely). However, the fact that capitalization rates are not approximately constant in the cross-sectional context means that the user cost and rental equivalence approaches to $\mathrm{OOH}$ can give very different answers, even in the long run. 
In the following section, we review the three main approaches to the treatment of owner-occupied housing in a CPI and discuss some of the difficulties associated with implementing each approach.

\subsection{Alternative Approaches for Pricing Owner-Occupied Housing}

For consumer durables that have long useful lives, the usual acquisitions approach will not be adequate for CPI users who desire prices that measure the service flows that consumer durables generate. This is particularly true for owner-occupied housing. Hence, it will be useful to many users if in addition to the acquisitions approach, the statistical agency implements both the rental equivalence approach and the user cost approach for long-lived consumer durables and for owner-occupied housing, in particular. ${ }^{79}$ Users can then decide which approach best suits their purposes. Any one of the three main approaches could be chosen as the approach that would be used in the headline CPI. The other two approaches should be made available to users as analytic tables. ${ }^{80}$

We conclude this section by outlining some of the problems involved in implementing the three main approaches to the measurement of price change for $\mathrm{OOH}$.

\subsubsection{The Acquisitions Approach}

In order to implement the acquisitions approach, a constant-quality price index for the sales of new residential housing units will be required. The hedonic regression approach to such price indexes outlined in section 12.7.3 seems to be the best approach to constructing such a constant-quality index.

\subsubsection{The Rental Equivalence Approach}

\section{Option 1: Using Homeowner's Estimates of Rents}

In this option, homeowners would be surveyed and asked to estimate a rental price for their housing unit. Problems with this approach are as follows:

- Homeowners may not be able to provide very accurate estimates for the rental value of their dwelling unit.

- The statistical agency should make an adjustment to these estimated rents over time in order to take into account the effects of depreciation,

79. Because the user cost and rental equivalence approaches will usually be quite different, users should be given the option of using either approach.

80. In section 12.11, we will suggest a fourth approach: the opportunity cost approach. This approach should also be made available to users in an analytical table. 
which cause the quality of the unit to slowly decline over time (unless this effect is offset by renovation and repair expenditures). ${ }^{81}$

- Care must be taken to determine exactly what extra services are included in the homeowner's estimated rent; that is, does the rent include insurance, electricity, fuel, or the use of various consumer durables in addition to the structure? If so, these extra services should be stripped out of the rent, because they are covered elsewhere in the CPI ${ }^{82}$

\section{Option 2: Using a Hedonic Regression Model of the Rental Market to Impute Rents}

In this option, the statistical agency would collect data on rental properties and their characteristics and then use this information to construct a hedonic regression model for the housing rental market. ${ }^{83}$ Then, this model would be used to impute prices for owner-occupied properties. Problems with this approach are as follows:

- It is information intensive; in addition to requiring information on the rents and characteristics of rental properties, information on the characteristics of owner-occupied properties would also be required.

- The characteristics of the owner-occupied population could be quite different from the characteristics of the rental population. In particular, if the rental market for housing is subject to rent controls, this approach is definitely not recommended.

- Hedonic regression models suffer from a lack of reproducibility, in that different researchers will have different characteristics in the model and will use different functional forms.

- From the discussion in section 12.9, it was seen that market rents may contain costs that are not relevant to homeowners, such as higher depreciation rates, billing costs, or higher opportunity costs of capital, and hence using market rents to impute rents for owner occupiers may lead to rents that are too high. ${ }^{84}$

81. Recall the discussion in section 12.8.4.

82. However, it could be argued that these extra services that might be included in the rent are mainly a weighting issue; that is, it could be argued that the trend in the homeowner's estimated rent would be a reasonably accurate estimate of the trend in the rents after adjusting for the extra services included in the rent.

83. See Crone, Nakamura, and Voith $(2000,2004)$ and Hoffmann and Kurz (2002) for examples of such hedonic models that try to cope with the heterogeneity in the rental market. Note that the U.S. Bureau of Labor Statistics selects a panel of rental units (drawn to match the corresponding owner stocks at a particular point in time), and then it computes a monthly rental equivalence index for the owner-occupied stock by aggregating up the price indexes for the chosen rental units; see Ptacek and Baskin (1996) for the details. This can be viewed as a simplified hedonic regression approach, where the characteristics of the owner-occupied stock of houses are rather roughly matched to corresponding rental units.

84. Again, it could argued that this is mainly a weighting issue; that is, it could be argued that the trend in market rents would be a reasonably accurate estimate for the trend in homeowners' opportunity costs. 
- There is some evidence that depreciation is somewhat different for rental units compared to owner-occupied housing units. ${ }^{85}$ If this is so, then the imputation procedure will be somewhat incorrect. However, all studies that estimate depreciation for owner-occupied housing suffer from biases due to the inadequate treatment of land and to the lack of information on repair, renovation, and maintenance expenditures over the life of the dwelling unit. Hence, it is not certain that depreciation for rental units is significantly different than that for owner-occupied units.

\subsubsection{The User Cost Approach}

It is first necessary to decide whether an ex ante or ex post user cost of housing is to be calculated. It seems that the ex ante approach is the more useful one for CPI purposes; these are the prices that should appear in economic models of consumer choice. Moreover, the ex post approach will lead to user costs that fluctuate too much to suit the needs of most users. Of course, the problem with the ex ante approach is that it will be difficult to estimate anticipated inflation rates for house prices.

\section{Option 3: The Rent-to-Value Approach}

In this option, the statistical agency collects information on market rents paid for a sample of rental properties, but it also collects information on the sales price of these rental properties when they are sold. Using these two pieces of information, the statistical agency can form an estimated rent-tovalue ratio for rental properties of various types. As was discussed in earlier sections, this rent-to-value ratio represents an estimate of all the terms that go into an ex ante user cost formula, except the asset price of the property; that is, the rent-to-value ratio for a particular property can be regarded as an estimate of the interest rate, less anticipated housing inflation, plus the depreciation rate, plus the other miscellaneous rates that were discussed in section 12.8, such as insurance and property tax rates. Under the assumptions that (a) these rates remain reasonably constant over the short run and (b) these rates are applicable to owner-occupied housing units, then an imputed rent for $\mathrm{OOH}$ is equal to the applicable rent-to-value ratio multiplied by the price of the owner-occupied unit. Thus, this approach can be implemented if a constant-quality price index for the stock value of owneroccupied housing can be developed. It may be decided to approximate the comprehensive price index for owner-occupied housing by a new housing price index, and if this is done, the approach essentially reduces down to

85. "The average depreciation rate for rental property is remarkably constant, ranging from 0.58 percent to 0.60 percent over the 25 year period. Depreciation rates for owner occupied units show more variation than the estimated rates for renter occupied units. The average depreciation rate for owner occupied housing ranges from 0.9 percent in year 1 to 0.28 percent in year 20" (Malpezzi, Ozanne, and Thibodeau 1987, 382). 
the acquisitions approach, except that the weights will generally be larger using this user cost approach than those obtained using the acquisitions approach. ${ }^{86}$ Problems with this approach include the following:

- It will require a considerable amount of resources to construct a constant-quality price index for the stock of owner-occupied housing units. If a hedonic regression model is used, there are problems associated with the reproducibility of the results.

- Rent-to-value ratios can change considerably over time. Hence, it will be necessary to collect information on rents and selling prices of rental properties on an ongoing basis.

- As was noted in section 12.9, the user cost structure of rental properties can be quite different from the corresponding user cost structure of owner-occupied properties. Hence, the use of rent-to-value ratios for rented dwellings can give misleading results when applied to owned structures. ${ }^{87}$

\section{Option 4: The Simplified User Cost Approach}

This approach is similar to that of Option 3, but instead of using the rent-to-value ratio to estimate the sum of the various rates in the user cost formula, direct estimates are made of these rates. If the simplified Icelandic user cost approach discussed in section 12.6 is used, all that is required is a constant-quality owner-occupied housing price index, an estimated real interest rate, and an estimated composite depreciation rate on the structure and land together. Problems with this approach are as follows:

- As was the case with Option 3, it will require a considerable amount of resources to construct a constant-quality price index for the stock of owner-occupied housing units. If a hedonic regression model is used, there are problems associated with the reproducibility of the results.

- It is not known with any degree of certainty what the appropriate real interest rate should be.

- Similarly, it is difficult to determine what the correct depreciation rate should be ${ }^{88}$ Moreover, this problem is complicated by the fact that over time, the price of land tends to increase faster than the price of building a residential structure, so the land price component of an owneroccupied housing unit will tend to increase in importance, which in turn will tend to decrease the composite depreciation rate.

86. See Diewert $(2002,618-9)$ on this point.

87. However, this is primarily a weighting issue, so the trend in the constant-quality stock of owner-occupied housing price index should be an adequate approximation to the trend in owner-occupied user costs.

88. Due to the lack of information on repairs and renovations, estimated housing depreciation rates vary widely: "One striking feature with the results of all three approaches used in these and related studies is their variability: estimates range from about a half percent per year to two and a half percent" (Malpezzi, Ozanne, and Thibodeau 1987, 373-5). 


\section{Option 5: A National Accounting Approach}

This approach makes use of the fact that the national accounts division of the statistical agency will usually collect data on investment in residential housing, as well as on repair and renovation expenditures on housing. In addition, many statistical agencies will also construct estimates for the stock of residential dwelling units, so estimates for the structures depreciation rates are available. Finally, if the statistical agency also constructs a national balance sheet, then estimates for the value of residential land will also be available. Thus, all of the basic ingredients that are necessary to construct stocks for residential structures and the associated land stocks are available. If in addition, assumptions about the appropriate nominal interest rate and about expected prices for structures and land are made, ${ }^{89}$ then aggregate user costs of residential structures and residential land can be constructed. The proportion of these stocks that is rented can be deducted, and estimates for the user costs and corresponding values for owner-occupied residential land and structures can be made. Of course, it would be almost impossible to do all of this on a current basis, but all of the previous computations can be done for a base period in order to obtain appropriate weights for owneroccupied structures and land. Then, it can be seen that the main drivers for the monthly user costs are the price of a new structure and the price of residential land. Hence, if timely monthly indicators for these two prices can be developed, the entire procedure is feasible. Problems with this approach include the following:

- As was the case with Option 4, it will be difficult to determine what the correct depreciation rates and real interest rates are..$^{90}$

- It will be difficult to construct a monthly price of residential land index.

- It may be difficult to convert the residential housing investment price deflator from a quarterly to a monthly basis.

All of the preceding five options for implementing a rental equivalence or user cost approach to modeling the cost of consuming the services of $\mathrm{OOH}$ have their advantages and disadvantages; there does not appear to be a clear winning option. ${ }^{91}$ Thus, each statistical agency will have to decide whether they have the resources to implement any of these five options in addition to the usual acquisitions approach to the treatment of owner-occupied housing. From the viewpoint of the cost-of-living approach to the CPI, any one

89. Alternatively, an appropriate real interest rate can be assumed.

90. However, as usual, it can be argued that errors in estimating these parameters will mainly affect the weights used in the price index.

91. For consumer durables that do not change in quality over time, Option 5 will probably suffice. Note that none of the five options includes the acquisitions approach, which is not a suitable approach for pricing the services of a long-lived durable good. 
of the five options would be an adequate approximation to the ideal treatment from the perspective of measuring the flow of consumption services in each period.

There is yet another approach to the treatment of $\mathrm{OOH}$, which we have not mentioned up to this point, because it is somewhat controversial and untried: the opportunity cost approach.$^{92}$ This final approach does not involve any new concepts and will be explained in the following section.

\subsection{The Opportunity Cost Approach to Owner-Occupied Housing}

Before presenting the opportunity cost approach to the treatment of $\mathrm{OOH}$ in a CPI, it will be useful to review Verbrugge's very interesting attack on the user cost approach to $\mathrm{OOH}$. His work also explains why user costs can diverge markedly from their corresponding market equivalent rents. $\mathrm{He}$ summarized his recent research as follows: ${ }^{93}$

I construct several estimates of ex ante user costs for US homeowners, and compare these to rents. There are three novel findings. First, a significant volatility divergence remains even for ex ante user cost measures which have been smoothed to mimic the implicit smoothing in the rent data. Indeed, the volatility of smoothed quarterly aggregate ex ante user cost growth is about 10 times greater than that of aggregate rent growth. This large volatility probably rules out the use of ex ante user costs as a measure of the costs of homeownership.... The second novel finding is perhaps more surprising: not only do rents and user costs diverge in the short run, but the gaps persist over extended periods of time. . . The divergence between rents and user costs highlights a puzzle, explored in greater depth below: rents do not appear to respond very strongly to their theoretical determinants. . . . Despite this divergence, the third novel finding is that there were evidently no unexploited profit opportunities. While the detached unit rental market is surprisingly thick, and detached housing is readily moved between owner and renter markets . . the large costs associated with real estate transactions would have prevented risk neutral investors from earning expected profits by using the transaction sequence buy, earn rent on property, sell, and would have prevented risk neutral homeowners from earning expected profits by using the transaction sequence sell, rent for one year, repurchase. (Verbrugge 2006, 3)

How did Verbrugge arrive at these conclusions? He started off with the following expression for the user cost $u_{i}^{t}$ of home $i:^{94}$

$$
u_{i}^{t}=P_{i}^{t}\left(i^{t}+\delta-E \pi_{i}^{t}\right),
$$

92. This approach was first suggested by Diewert $(2009,113)$.

93. Verbrugge's initial research has recently been updated in Garner and Verbrugge (2009), but this updated research did not change the conclusions listed in his original study.

94. See equation (1) in Verbrugge $(2006,11)$. Note that this formula is a counterpart to equation (9) in this chapter. 
where $P_{i}^{t}$ is the price of home $i$ in period $t ; i^{t}$ is a nominal interest rate; ${ }^{95} \delta$ is the sum of annual depreciation, maintenance and repair, insurance, property taxes, and a potential risk premium; ${ }^{96}$ and $E \pi_{i}^{t}$ represents the expected annual constant-quality home appreciation rate for home $i$ at period $t .{ }^{97}$ Thus, the resulting user cost can be viewed as an opportunity cost measure for the annual cost of owning a home, starting at the beginning of the quarter indexed by time $t$. As was noted earlier in this chapter, when landlords set an annual rent for a dwelling unit, they would use a formula similar to equation (55) in order to determine the rent for a tenant. ${ }^{98}$ So far, there is nothing particularly controversial about Verbrugge's analysis. What is controversial is Verbrugge's determination of the expected house price appreciation term, $E \pi_{i}^{t}$.

Rather than using a crude proxy, I will construct a forecast for $E \pi_{i}^{t}$, as described below. This choice is crucial, for four reasons. First, expected home price appreciation is extremely volatile; setting this term to a constant is strongly at odds with the data, and its level of volatility will be central to this study. Second, this term varies considerably across cities, and its temporal dynamics might well vary across cities as well. Third, the properties of $\left(i^{t}-E \pi_{i}^{t}\right)$ are central to user cost dynamics, yet these properties are unknown (or at least, not documented); again, setting $E \pi_{i}^{t}$ to a constant (or even to a long moving average) would be inappropriate for this study, since this choice obviously suppresses the correlation between $i^{t}$ and $E \pi_{i}^{t}$. Finally, the recent surge in $E \pi_{i}^{t}$ is well above its 15 year average, and implies that the user cost/rent ratio has fallen dramatically. A single year appreciation rate is used since we are considering the one year user cost, in order to remain comparable to the typical rental contract. (Verbrugge 2006, 12)

Verbrugge $(2006,13)$ went on to use various econometric forecasting techniques to forecast expected price appreciation for his one-year horizon; he inserted these forecasts into the user cost formula in equation (55) and obtained tremendously volatile ex ante user costs. The rest of his conclusions followed.

However, it is unlikely that landlords use econometric forecasts of housing price appreciation one year away and adjust rents for their tenants every year based on these forecasts. Tenants do not like tremendous volatility in

95. Verbrugge $(2006,11)$ used either the current thirty-year mortgage rate or the average one-year Treasury bill rate and noted that the choice of interest rate turned out to be inconsequential for his analysis.

96. Verbrugge $(2006,13)$ assumed that $\delta$ was approximately equal to 7 percent. Note that the higher the volatility in house prices is, the higher the risk premium would be for a risk-averse consumer.

97. The variable $\pi_{i}^{t}$ is the actual four-quarter (constant-quality) home price appreciation between the beginning of period $t$ and one year from this period.

98. As was noted in sections 12.8 and 12.9, there are some differences between a user cost formula for an owner occupier as compared to a landlord, but these differences are not important for Verbrugge's analysis. 
their rents, and any landlord that attempted to set such volatile rents would soon have very high vacancy rates on his or her properties. However, it is possible that landlords may have some idea of the long-run average rate of property inflation for the type of property that they manage, and this longrun average annual rate of price appreciation could be inserted into the user cost formula in equation (55). ${ }^{99}$

Looking at the opportunity costs of owning a house from the viewpoint of an owner occupier, the relevant time horizon to consider for working out an annualized average rate of expected price appreciation is the expected time that the owner expects to use the dwelling before reselling it. This time horizon is typically some number between six and twelve years, so again, it does not seem appropriate to stick annual forecasts of expected price inflation into the user cost formula. Once we use annualized forecasts of expected price inflation over longer time horizons, the volatility in the ex ante user cost formula will vanish, or at least will be much diminished. ${ }^{100}$

Another method for reducing the volatility in the user cost formula is to replace the nominal interest rate, less expected price appreciation term $\left(i^{t}-E \pi_{i}^{t}\right)$, by a constant or slowly changing long-run average real interest rate, say $r^{t}$. This is what was done in Iceland, as noted in section 12.6, and the resulting user cost seems to be acceptable to the population (and it is not overly volatile).

Verbrugge had an interesting section in his paper that helps to explain why user costs and market rentals can diverge so much over the short run. The answer is that high transactions costs involved in selling or purchasing real estate properties prevent arbitrage opportunities: ${ }^{101}$

The first question is thus answered: there is no evidence of unexploited profits for prospective landlords. How about the second: was there ever a period of time in any city during which a "median" homeowner should have sold his house, rented for a year, and repurchased his house a year later?. . . In this case, it appears that for Los Angeles, there was a single year, 1994, during which a homeowner should have sold her house, rented for a year, and repurchased her house. For every other time period, and for the entire period for the other four cities, a homeowner was always better off remaining in his house. (Verbrugge 2006, 36)

99. The paper by Girouard et al. nicely documents the length of housing booms and busts: "To qualify as a major cycle, the appreciation had to feature a cumulative real price increase equaling or exceeding 15 percent. This criterion identified 37 such episodes, corresponding to about two large upswings on average per 35 years for English speaking and Nordic countries and to $11 / 2$ for the continental European countries" $(2006,6)$. Thus, one could justify taking ten- to twenty-year (annualized) average rates of property price inflation in the user cost formula rather than one-year rates.

100. Garner and Verbrugge $(2009,139)$ noted that volatility in their forecasted user costs dropped to about one-fifth of the previous level when one-year forecasts of expected house price inflation were replaced by five-year forecasts.

101. Verbrugge $(2006,35)$ assumed that the transactions costs in the United States were approximately 8 to 10 percent of the sales price. 
Because high real estate transactions costs prevent the exploitation of arbitrage opportunities between owning and renting a property, user costs can differ considerably over the corresponding rental equivalence measures over the lifetime of a property cycle.

There is another puzzle in the behavior of user costs versus market rental prices that Verbrugge (2006) and Garner and Verbrugge (2009) did not comment on - the puzzling decrease in the ratio of market rents to housing price as the house price increases, as noted in section 12.9. This phenomenon seems to indicate that the rental market for housing for relatively inexpensive housing is at least somewhat segmented from the higher-end rental market. This segmentation could be explained as follows: as family income grows, people tend to want to own their own home, because this provides more security of tenure compared to renting. ${ }^{102}$ Thus, the active rental market for housing is mostly geared toward low-income families. On the other hand, if an owner of an expensive unit wishes to rent the unit to someone else (perhaps for temporary purposes or to simply have someone reliable to occupy the property), the rental rate must be relatively low in order to induce a relatively low-income renter to occupy the property. In any case, it seems clear that user costs do not always equal the corresponding market rental rates.

Note that the user cost and the market equivalent rent that an owneroccupied house can generate are both opportunity costs that can be associated with that housing unit: the user cost is a somewhat indirect financial capital opportunity cost, whereas the market equivalent rent is a more direct opportunity cost. But the true opportunity cost of housing for an owner occupier is not his or her internal user cost or the market equivalent rent but instead is the maximum of the internal user cost and what the property could rent for on the rental market. ${ }^{103}$ After all, the concept of opportunity cost is supposed to represent the maximum sacrifice that one makes in order to consume or use some object, so this point would seem to follow. If this point of view is accepted, then at certain points in the property cycle, user costs would replace market rents as the correct pricing concept for owneroccupied housing, ${ }^{104}$ which would dramatically affect CPIs and the conduct of monetary policy. This point also indicates the need for statistical agencies to produce both user costs and equivalent rent price series for their CPI users. This opportunity cost approach to pricing the services of durable assets could also be used in production and productivity accounts, and this treatment would eliminate the problem of negative user costs, because market rents would always be nonnegative.

In conclusion, we suggest that the best pricing concept for the services of

102. There are typically tax advantages to owning over renting, as well.

103. See Diewert $(2009,113)$.

104. Garner and Verbrugge (2009) look at the levels of user costs and market rents in five U.S. cities and find that user costs are sometimes above and sometimes below their corresponding estimates of market rents. 
$\mathrm{OOH}$ is the opportunity cost approach, which is equal to the maximum of the market rental and the ex ante user cost for any particular property.

\section{References}

Aizcorbe, A., C. Corrado, and M. Doms. 2001. Constructing price and quantity indexes for high technology goods. Industrial Output Section, Division of Research and Statistics. Washington, DC: Board of Governors of the Federal Reserve System, July.

Bailey, M. J., R. F. Muth, and H. O. Nourse. 1963. A regression method for real estate price construction. Journal of the American Statistical Association 58:933-42.

Baldwin, J., G. Gellatly, M. Tanguay, and A. Patry. 2005. Estimating depreciation rates for the productivity accounts. Paper presented at the Organization for Economic Cooperation and Development (OECD) Workshop on Productivity Measurement. 17-19 October, Madrid, Spain.

Beidelman, C. R. 1973. Valuation of used capital assets. Sarasota, FL: American Accounting Association.

. 1976. Economic depreciation in a capital goods industry. National Tax Journal 29 (4): 379-90.

Boskin, M. J., E. Dulberger, R. Gordon, Z. Griliches, and D. W. Jorgenson. 1996. Toward a more accurate measure of the cost of living. Final Report to the Senate Finance Committee from the Advisory Committee to Study the Consumer Price Index. Washington, DC: Government Printing Office, December.

Branson, M. 2006. The Australian experience in developing an established house price index. Paper presented at the OECD and International Monetary Fund (IMF) Workshop on Real Estate Price Indexes. 6-7 November, Paris.

Case, K. E., and R. J. Shiller. 1989. The efficiency of the market for single family homes. American Economic Review 79 (1): 125-37.

Christensen, L. R., and D. W. Jorgenson. 1969. The measurement of U.S. real capital input, 1929-1967. Review of Income and Wealth 15 (4): 293-320.

Court, A. T. 1939. Hedonic price indexes with automotive examples. In The dynamics of automobile demand, 98-117. New York: General Motors Corporation.

Crone, T. M., L. I. Nakamura, and R. Voith. 2000. Measuring housing services inflation. Journal of Economic and Social Measurement 26 (3/4): 153-71.

2004. Hedonic estimates of the cost of housing services: Rental and owneroccupied units. Working Paper no. 04-22. Federal Reserve Bank of Philadelphia, Research Department.

de Haan, J. 2003. Time dummy approaches to hedonic price measurement. Paper presented at the Seventh Ottawa Group Meeting on Price Indices. 27-29, May, Paris. Available at: http://www.insee.fr/en/nom_def_met/colloques/ottawa/ ottawa_papers.htm.

2004. Hedonic regressions: The time dummy index as a special case of the Törnqvist Index, time dummy approaches to hedonic price measurement. Paper presented at the Statistics Finland Eighth Meeting of the International Working Group on Price Indices. 23-25 August, Helsinki, Finland.

Diewert, W. E. 1974. Intertemporal consumer theory and the demand for durables. Econometrica 42 (3): 497-516.

1980. Aggregation problems in the measurement of capital. In The measurement of capital, ed. D. Usher, 433-528. Chicago: University of Chicago Press. 
2002. Harmonized indexes of consumer prices: Their conceptual foundations. Swiss Journal of Economics and Statistics 138 (4): 547-637.

2003a. Hedonic regressions: A consumer theory approach. In Studies in income and wealth, vol. 64, Scanner data and price indexes, ed. R. C. Feenstra and M. D. Shapiro, 317-48. Chicago: University of Chicago Press.

2003b. Hedonic regressions: A review of some unresolved issues. Paper presented at the Seventh Ottawa Group Meeting on Price Indices. 27-29 May, Paris. Available at http://www.insee.fr/en/av_service/colloques/ottawa/ottawa_papers .htm.

2003c. The treatment of owner occupied housing and other durables in a consumer price index. Discussion Paper no. 03-08. University of British Columbia, Department of Economics.

. 2005a. Issues in the measurement of capital services, depreciation, asset price changes and interest rates. In Measuring capital in the new economy, ed. C. Corrado, J. Haltiwanger, and D. Sichel, 479-542. Chicago: University of Chicago Press.

2005b. Weighted country product dummy variable regressions and index number formulae. Review of Income and Wealth 51 (4): 561-71.

. 2006. Adjacent period dummy variable hedonic regressions and bilateral index number theory. Annales d'économie et de statistique, no. 79/80, 1-28.

. 2009. The Paris OECD-IMF Workshop on real estate price indexes: Conclusions and future directions. In Price and productivity measurement, vol. 1, Housing, ed. W. E. Diewert, B. M. Balk, D. Fixler, K. J. Fox and A. O. Nakamura, 87-116. Victoria, B.C.: Trafford Press. Available at: www.vancouvervolumes.com.

Diewert, W. E., and D. A. Lawrence. 2000. Progress in measuring the price and quantity of capital. In Econometrics, vol. 2, Econometrics and the cost of capital: Essays in honor of Dale W. Jorgenson, ed. L. J. Lau, 273-326. Cambridge, MA: MIT Press.

Diewert, W. E., and F. C. Wykoff. 2007. Depreciation, deterioration and obsolescence when there is embodied or disembodied technical change. University of British Columbia, Department of Economics. Working Paper. Available at http:// www.econ.ubc.ca/diewert/dp0602.pdf.

Eurostat, World Bank, International Monetary Fund, Organization for Economic Cooperation and Development, and United Nations. 1993. System of National Accounts, 1993. New York: United Nations.

Eurostat. 2001. Handbook on price and volume measures in national accounts. Luxembourg: European Commission.

Garner, T. I., G. Janini, W. Passero, L. Paszkiewicz, and M. Vendemia. 2003. The consumer expenditure survey in comparison: Focus on personal consumption expenditures. Paper presented at the meeting of the BLS Federal Economic Statistics Advisory Committee. 21 March, Washington, DC. Available at http:// www.bls.gov/bls/fesacp1032103.pdf.

Garner, T. I., and K. Short. 2001. Owner-occupied shelter in experimental poverty measurement with a "look" at inequality and poverty rates. Paper presented at the annual meeting of the Southern Economics Association. November, Tampa, FL.

Garner, T. I., and R. Verbrugge. 2009. The puzzling divergence of rents and user costs, 1980-2004: Summary and extensions. In Price and productivity measurement, Vol. 1, Housing, ed. W. E. Diewert, B. M. Balk, D. Fixler, K. J. Fox, and A. O. Nakamura, 125-46. Victoria, B.C.: Trafford Press. Available at: http://www. vancouvervolumes.com.

Gilman, S. 1939. Accounting concepts of profit. New York: Rolland Press.

Girouard, N., M. Kennedy, P. van den Noord, and C. André. 2006. Recent house price developments: The role of fundamentals. Paper presented at the OECD-IMF 
Workshop on Real Estate Price Indexes. 6-7 November, Paris. Available at: http://www.oecd.org/dataoecd/3/6/37583208.pdf

Goodhart, C. 2001. What weights should be given to asset prices in the measurement of inflation? Economic Journal 111 (June): F335-F356.

Gouriéroux, C., and A. Laferrère. 2006. Managing hedonic housing price indexes: The French experience. Paper presented at the OECD-IMF Workshop on Real Estate Price Indexes. 6-7 November, Paris. Available at: http://www.oecd.org/ dataoecd/2/24/37583497.pdf.

Griliches, Z. 1971a. Hedonic price indexes for automobiles: An econometric analysis of quality change. In Price indexes and quality change, ed. Z. Griliches, 55-87. Cambridge, MA: Harvard University Press.

. 1971b. Introduction: Hedonic price indexes revisited. In Price indexes and quality change, ed. Z. Griliches, 3-15. Cambridge, MA: Harvard University Press.

Gudnason, R. 2003. How do we measure inflation? Some measurement problems. Paper presented at the Seventh Ottawa Group Meeting on Price Indices. 27-29 May, Paris. Available at: http://www.insee.fr/en/av_service/colloques/ottawa/ ottawa_papers.htm.

Gudnason, R., and G. R. Jónsdóttir. 2009. Owner occupied housing in the Icelandic CPI. In Price and productivity measurement, vol. 1, Housing, ed. W. E. Diewert, B. M. Balk, D. Fixler, K. J. Fox, and A. O. Nakamura, 147-50. Victoria, B.C.: Trafford Press. Available at: www.vancouvervolumes.com.

Hall, R. E. 1971. The measurement of quality change from vintage price data. In Price indexes and quality change, ed. Z. Griliches, 240-71. Cambridge, MA: Harvard University Press.

Harper, M. J., E. R. Berndt, and D. O. Wood. 1989. Rates of return and capital aggregation using alternative rental prices. In Technology and capital formation, ed. D. W. Jorgenson and R. Landau, 331-72. Cambridge, MA: MIT Press.

Heravi, S., and M. Silver. 2007. Different approaches to estimating hedonic indexes. In Studies in Income and Wealth, vol. 67, Hard-to-measure goods and services: Essays in honor of Zvi Griliches, ed. E. R. Berndt and C. Hulten, 235-69. Chicago: University of Chicago Press.

Heston, A., and A. Nakamura. 2009. Reported prices and rents of housing: Reflections of costs, amenities or both? In Price and productivity measurement, Vol. 1, Housing, ed. W. E. Diewert, B. M. Balk, D. Fixler, K. J. Fox, and A. O. Nakamura, 117-24. Victoria, B.C.: Trafford Press. Available at: www.vancouvervolumes .com.

Hicks, J. R. 1946. Value and capital. 2nd ed. Oxford: Clarendon Press.

Hoffmann, J., and C. Kurz. 2002. Rent indices for housing in West Germany: 1985 to 1998. Discussion Paper no. 01/02. Deutsche Bundesbank, Economic Research Center.

Hoffmann, J., and A. Lorenz. 2006. Real estate price indices for Germany: Past, present and future. Paper presented at the OECD-IMF Workshop on Real Estate Price Indexes, 6-7 November, Paris. Available at: http://www.oecd.org/dataoecd/ 31/20/37625451.pdf.

Hulten, C. R. 1990. The measurement of capital. In Fifty years of economic measurement, ed. E. R. Berndt and J. E. Triplett, 119-58. Chicago: University of Chicago Press.

1996. Capital and wealth in the revised SNA. In The New System of National Accounts, ed. J. W. Kendrick, 149-81. New York: Kluwer Academic Publishers.

. 2006. The "architecture" of capital accounting: Basic design principles. In Studies in income and wealth, vol. 66, A new architecture for the U.S. national 
accounts, ed. D. W. Jorgenson, J. S. Landefeld, and W. E. Nordhaus, 193-214. Chicago: University of Chicago Press.

Hulten, C. R., and F. C. Wykoff. 1981a. The estimation of economic depreciation using vintage asset prices. Journal of Econometrics 15 (3): 367-96.

1981b. The measurement of economic depreciation. In Depreciation, inflation and the taxation of income from capital, ed. C. R. Hulten, 81-125. Washington, DC: Urban Institute Press.

1996. Issues in the measurement of economic depreciation: Introductory remarks. Economic Inquiry 34 (1): 10-23.

International Labor Organization (ILO), in collaboration with the IMF, OECD, United Nations Economic Commission for Europe (UNECE), Eurostat, and the World Bank. 2004. Consumer Price Index manual: Theory and practice. Geneva: ILO.

Jorgenson, D. W. 1973. The economic theory of replacement and depreciation. In Econometrics and economic theory, ed. W. Sellekaerts, 189-221. New York: Macmillan.

1989. Capital as a factor of production. In Technology and capital formation, ed. D. W. Jorgenson and R. Landau, 1-35. Cambridge, MA: MIT Press. 1996. Empirical studies of depreciation. Economic Inquiry 34 (1): 24-42.

Katz, A. J. 1983. Valuing the services of consumer durables. Review of Income and Wealth 29 (4): 405-27.

Lebow, D. E., and J. B. Rudd. 2003. Measurement error in the Consumer Price Index: Where do we stand? Journal of Economic Literature 41 (1): 159-201.

Leigh, W. A. 1980. Economic depreciation of the residential housing stock of the United States, 1950-1970. Review of Economics and Statistics 62 (2): 200-6.

Li, W., M. Prud'homme, and K. Yu. 2006. Studies in hedonic resale housing price indexes. Paper presented at the OECD-IMF Workshop on Real Estate Price Indexes. 6-7 November, Paris. Available at: http://www.oecd.org/dataoecd/ 2/25/37583404.pdf.

Malpezzi, S., L. Ozanne, and T. Thibodeau. 1987. Microeconomic estimates of housing depreciation. Land Economics 63 (4): 372-85.

Marshall, A. 1898. Principles of economics. 4th ed. London: Macmillan.

Palmquist, R. B. 2006. Property value models. In Handbook of environmental economics, vol. 2, ed. K. -G. Mäler and J. Vincent, 763-819. Amsterdam: NorthHolland.

Prasad, N., and A. Richards. 2006. Measuring aggregate house prices in Australian capital cities: A review of RBA research. Paper presented at the Economic Measurement Group Workshop. 13-15 December, Coogee, Australia. Available at: http://www.sam.sdu.dk/parn/EMG\%20Workshop\%20'06\%20program.pdf.

Ptacek, F., and R. M. Baskin. 1996. Revision of the CPI housing sample and estimators. Monthly Labor Review 119 (12): 31-39.

Silver, M., and S. Heravi. 2003. The measurement of quality adjusted price changes. In Studies in income and wealth, vol. 64, Scanner data and price indexes, ed. R. C. Feenstra and M. D. Shapiro, 277-316. Chicago: University of Chicago Press. 2007. The difference between hedonic imputation indexes and time dummy hedonic indexes. Journal of Business and Economic Statistics 25 (2): 239-46.

Solomons, D. 1961. Economic and accounting concepts of income. Accounting Review 36 (4): 374-83.

Statistics Canada. 2007. Depreciation rates for the productivity accounts. Canadian Productivity Review, no. 005, catalog no. 15-206-XIE. Microeconomics Analysis Division, Statistics Canada. Available at: http://www.statcan.gc.ca/pub/15-206-x/ 15-206-x2007005-eng.pdf. 
Summers, R. 1973. International comparisons with incomplete data. Review of Income and Wealth 29 (1): 1-16.

Triplett, J. 2004. Handbook on hedonic indexes and quality adjustments in price indexes: Special application to information technology products. STI Working Paper no. 2004/9. OECD Directorate for Science, Technology and Industry. Available at: http://www.oecd.org.dataoecd/37/31/33789552.pdf.

U.S. Department of Labor, Bureau of Labor Statistics (BLS). 1983. Changing the home ownership component of the Consumer Price Index to rental equivalence. CPI detailed report, January: 7-13.

van den Bergen, D., M. de Haan, R. de Heij, and M. Horsten. 2005. Measuring capital in the Netherlands. Paper presented at the Meeting of the OECD Working Party on National Accounts. 11-14 October, Paris.

Verbrugge, R. 2006. The puzzling divergence of rents and user costs, 1980-2004. Paper presented at the OECD-IMF Workshop on Real Estate Price Indexes. 6-7 November, Paris. Available at: http://www.oecd.org/dataoecd/42/57/37612870.pdf.

Walras, L. 1954. Elements of pure economics. Trans. W. Jaffe. London: George Allen and Unwin. (orig.pub. 1874.)

Wenzlick, R. 1952. As I see the fluctuations in the selling prices of single family residences. Real Estate Analyst 21 (December 24): 541-8.

Woolford, K. 1999. Measuring inflation: A framework based on domestic final purchases. In Proceedings of the Measurement of Inflation Conference, ed. M. Silver and D. Fenwick, 534-43. Wales, U.K.: Cardiff University.

Wyngarden, H. 1927. An index of local real estate prices. Vol. 1, no. 2 of Michigan business studies. Ann Arbor: University of Michigan.

\section{Comments Alan Heston}

Diewert brings to this chapter on the valuation of services flowing from durable assets a strong background rooted in academic conferences, the development of Organization for Economic Cooperation and Development (OECD) manuals, and hands-on experience with country methods. More recently, Diewert has been involved in contributing to manuals on national and international consumer price indexes and with advising governments on the subject of chapter 12 in this volume: the treatment of time-to-time indexes of owner-occupied housing $(\mathrm{OOH})$. The chapter is long and rich in detail, providing a significant conceptual discussion and a panoramic view of how price statisticians have dealt in practice with measuring rental service flows for what is now the largest component of consumer expenditures in middle-, high-, and many low-income countries. Diewert has long advocated the user cost approach in most estimates of service flows from durables, and not surprisingly, compared to the net acquisitions and rental equivalence approaches, he devotes more space to user cost in his conceptual discussion of $\mathrm{OOH}$. 